\title{
[4] Pandora's Box
}

\section{Transgressions}

Neither Baudelairean nor Lombrosian, the rhetoric of sickness as applied to the upper-class female body might be labeled specifically D'Annunzian, for it constitutes the erotic discourse of the Romanzi della Rosa. Convalescence appears once again, and once again as the identity of the convalescent is altered, so too is the ideology thus embodied.

The sickness from which the upper-class female character convalesces is often of a specifically female sort, as Mario Praz has noted in The Romantic Agony:

Both Tullio Hermil and Giorgio Aurispa have intercourse with women whoare scarcely convalescent from diseases of the womb [malattie della matrice]. Elena gives herself to Sperelli when she is ill. In Ippolita Giorgio possesses an epileptic, and Paolo Tarsis, in Isabella Inghirami, a lunatic. Sterility also, a characteristic of D'Annunzio's women, acts as a sadistic stimulus. "She is sterile. Her womb is accursed. . . The uselessness of her love seemed to him a monstrous transgression against the supreme law" (Trionfo della morte, p. 361). Giorgio Aurispa is especially attracted by the bodily defects of Ippolita: "The most vulgar features had an irritating attraction for him" (p. 360). Stelio Effrena is excited by the faisandage of la Foscarina. A 
"transgression" from the normal, in fact, seems to be a sine qua non of D'Annunzio's love stories.

Praz's reading of sickness and sterility in D'Annunzio's female characters well represents the doxa of D'Annunzian criticism: sterility renders the woman a perfect instrument of voluptuous pleasure, sickness renders her a ready-made victim of the male protagonist's sadistic impulses. This reading, it should be noted, is less an interpretation than a repetition of the texts themselves. Tullio Hermil makes no bones about "la tanto esecrata perversione sadica" ["the so often execrated sadistic perversion"], and it is the narrator of Trionfo della morte who explains that Ippolita's sterility makes her "un più prezioso strumento di voluttà" ["a more precious instrument of voluptuousness"]. ${ }^{2}$ Yet Praz's observation that a transgression of a norm is necessary to D'Annunzio's erotic discourse seems as unconfutable as it is generic. Indeed, though Praz seems to limit this characteristic of erotic discourse to decadent writers of the likes of D'Annunzio, Baudelaire, and Swinburne, Georges Bataille, in L'bistoire de l'érotisme, expands it to eroticism in general:

The history of eroticism is not at all that of sexual activity allowed within the limits defined by infractions of rules. It is always a matter of going beyond the admissible limits: there is nothing erotic in sexual play that resembles that of animals. And perhaps eroticism is relatively rare (it is difficult to determine on account of the small amount of certain information we have): it consists in the fact that some received forms of sexual excitment take place in such a way that they are no longer receivable. It is therefore a matter of passing from the licit to the prohibited. The sexual life of man arose from the accursed, probibited domain, not from the licit domain. ${ }^{3}$

1. Mario Praz, The Romantic Agony, trans. Angus Davidson, with a foreword by Frank Kermode (1951; rpt. London: Oxford University Press, 1978), 267.

2. Gabriele D'Annunzio, L'Innocente, in Prose di romanzi, Tutte le opere di Gabriele D'Annunzio, ed. Egidio Bianchetti (Milan: Mondadori, 1955), 1:394; D'Annunzio, Trionfo della morte, in Prose di romanzi, 1:1033.

3. Georges Bataille, L'bistoire de l'érotisme, in Oeuvres complètes (Paris: Gallimard, 1976), 8:108. 
Without prohibitions and transgressions there can, for Bataille as well as for D'Annunzio, be no eroticism. That D'Annunzio's erotic discourse concurs with Bataille's analysis is perhaps less interesting than the specific nature of the prohibitions transgressed in D'Annunzio's Romanzi della Rosa. Why, we might ask, should sickness constitute a prohibition at all? Naturalistic explanations are rendered inadequate by the nature of the diseases involved. In the three novels in question those diseases are not (at least medically speaking) communicable ones but instead, as Praz has observed, "malattie della matrice" and epilepsy. In fact, both diseases are particularly suited to constitute prohibitions not because, naturalistically speaking, they inhibit the sexual act, but because they are both figured as sacred diseases. Vivifying etymological and mythological connections, D'Annunzio attributes vaguely diagnosed uterine dysfunction to the action of "il dèmone isterico," and Ippolita's epilepsy is most often referred to as "il male sacro." The transgression seems thus not of social or medical norms but of some other, "divine" law established by the text.

This rhetoric of sickness, which evokes both sacred and demonic, is the erotic discourse of the Romanzi della Rosa. Broadly speaking, there is a movement in the trilogy from an eroticization of female sickness in Il piacere to its total deeroticization in Trionfo della morte. The erotic effect of such illnesses upon the male protagonist undergoes an apparent cyclical evolution, tracing what Paolo Valesio has described as the ideological frame that shapes D' Annunzio's erotic politics in general: "The symbolic action of erotic relationships in D'Annunzio's novels follows, generally, a basic double movement: first a movement of triumphant assertion (conquest, enjoyment), soon followed by dissatisfaction, repentance, and a general flight away from the flesh and its "pleasures." could stand as an accurate thematic description of the entire cycle of the Romanzi della Rosa, with Il piacere as the moment of conquest and enjoyment, L'Innocente as the moment of repentance, and Trionfo della morte as the moment of the flight from the flesh. The final "flight" of Trionfo della morte, however, marks the beginning of some other "phase" only in the sense that it leads to a "refinement"

4. Paolo Valesio, "The Lion and the Ass: The Case for D'Annunzio's Novels," Yale Italian Studies 1.1 (1977): 71. 
of the preceding movement. D'Annunzio's experiment with physiological description seems to end with Trionfo della morte, not only because of his acquaintance with Nietzsche's philosophy, but because his modern "romance of the rose" is already an unveiling that concludes that veils are necessary. In Le vergini delle rocce we no longer find an alternation between conquest and revulsion, nor do we find physiological descriptions of either male protagonist or female object of desire. The rhetorical strategy of Le vergini delle rocce is that of allegoresis, and the erotic discourse in that work, as well as in La Gioconda and Il fuoco, is essentially a fetishistic one that eroticizes "dismembered" objects-hair, voice, hands-and avoids any description of the "rose" itself.' We might therefore rewrite the "ideological frame" in less Christian terms (or at least as doubting Thomas rather than penitent sinner) as a moment of revelation followed by disbelief and, finally, disavowal, for an unveiling that concludes that veils are necessary is nothing other than the fetishist's disavowal. ${ }^{6}$ In differing forms, the novels of the trilogy narrativize the logic of fetishism, and the "law" transgressed is the law that constitutes sexual difference.

\section{The Hysterical Demon}

Physiological description of specifically female ailments is limited to several apparently isolated episodes in Il piacere. Sperelli lives in anticipation of conquest for the greater part of the novel, and moments of revelation are few. Those few moments coincide

5. For a discussion of allegoresis in Le vergini delle rocce, see Lucia Re, “Gabriele D'Annunzio's Novel Le vergini delle rocce: 'Una cosa naturale vista in un grande specchio," Stanford Italian Review 3 (Fall 1983): 241-71.

6. The Nietzschean ring to this formulation is intentional. See the Preface to The Gay Science, ed. and trans. Walter Kauf mann (1887; New York: Vintage Books, 1974), 38: "We no longer believe that truth remains truth when the veils are withdrawn." See Sarah Kofman's analysis of the relation between veils and fetishism in her chapter "Baubo: Perversion théologique et fétichisme," in Nietzsche et la scène philosophique (Paris: Union Générale d'Editions, 1979), as well as Derrida's discussion of truth and veils in Spurs: Nietzsche's Styles/Eperons: Les styles de Nietzsche, trans. Barbara Harlow (Chicago: University of Chicago Press, 1979). 
with the appearance of a rhetoric of sickness and are the germ of the (repulsive) revelation that will become the dominant tone of Trionfo della morte, and of the fetishistic revelation manqué of $\mathrm{La}$ Gioconda.

As Praz has noted, Sperelli and Elena first consummate their flirtation in Elena's sickbed. The malady from which she suffers appears to be the "nevralgie della faccia" ["neuralgia of the face"] mentioned as an affliction to which Elena is prone. It remains unnamed in the scene and we learn only that "la signora soff riva molto e che non poteva veder nessuno" ["the lady suffered greatly and could not see anyone"]. ${ }^{7}$ Sperelli, however, an exception to this rule, is allowed to enter the sickroom. As he crosses the threshold, he is struck by an odor: "Ebbe, da prima, l'impressione d'un'aria assai calda, quasi soffocante; sentì nell'aria l'odore singolare del cloroformio" (Il piacere, 85) ["He had at first the impression of rather hot, almost stifling air; he smelled the singular odor of chloroform"]. The presence of chloroform in the sickroom might suggest that "vapors" or "female troubles" are being treated, though the pain from which Elena suffers is localized in the face: "Gli angoli esterni delle palpebre si restringevano per la contrazion dolorosa dei nervi infiammati" (Il piacere, 85) ["The outer corners of her eyelids were contracted by the pain of her inflamed nerves"]. ${ }^{8}$ But if the first mention of chloroform, as Sperelli enters the room, is an indicator of Elena's pain, the second, upon his exit, links the sickroom to pleasure, to an erotic effect upon Sperelli: "Gli persisteva nel senso l'odore di cloroformio, simile a un vapore di ebrezza" (Il piacere, 88) ["The odor of chloroform lingered in his senses, like an intoxicating vapor"]. This hint of an eroticization of sickness is not developed further in $I l$ piacere, but remains a suggestion which will be taken up in L'Innocente, for one of the threads of continuity between the two novels can be traced from the sickbed seduction in Il piacere to Giuliana, who rarely leaves her sickbed in L'Innocente.

Giuliana is permanently convalescent in L'Innocente; the surgery

7. Gabriele D'Annunzio, Il piacere, in Prose di romanzi, 1:81.

8. Chloroform was available as a pain-killer, used in particular to ease the pains of childbirth, from 1847 on. Its growing use in obstetrics and gynecology was controversial in the latter half of the century, as Peter Gay documents in Education of the Senses, vol. 1 of The Bourgeois Experience: Victoria to Freud (New York: Oxford University Press, 1984), 226-33. 
she undergoes in the incipit is followed by a long convalescence from which she emerges not healthy but pregnant. In her already weakened condition, that pregnancy becomes yet another illness that confines her to her bed until childbirth nearly causes her death. Giuliana manages to get out of bed only long enough to get into bed with Filippo Arborio. This eternally bedridden woman is a phenomenon of the nineteenth century well documented by social historians. ${ }^{9}$ Giuliana might be said, in fact, to be a textbook case of female invalidism. As Barbara Ehrenreich and Deirdre English point out in their book on the sexual politics of sickness, "Not only were women seen as sickly — sickness was seen as feminine." 10 True to this ideologeme of the sick woman, Giuliana's invalidism, her languor and unearthly pallor render her all the more desirable. In L'Innocente, the femininity of sickness is overdetermined, for we find not merely a sick woman but a woman who suff ers from "female troubles," from "malattie complicate della matrice e dell'ovaia" (L'Innocente, 378) ["complicated disease of the womb and of the ovaries"].

The female troubles that plague Sperelli are of a different sort. The scene of Sperelli's convalescence, from which Elena is necessarily excluded, terminates their affair. When Sperelli returns in book 3 to his life of pleasure, the valence carried by female pathology is no longer a positive one.

The dinner scene that opens book 3 marks Andrea's return to Roman high society and to the "perversion" that had preceded his short-lived conversion to art. This return to perversion is figured as a return of the physiology so carefully avoided in the scene of convalescence. The androgynous Maria, the ventriloquist's ideal, is supplanted by the hermaphroditic Bébé Silva, who becomes a caricature of both Maria and the feminized Sperelli:

9. See, for example, Elaine Showalter, The Female Malady: Women, Madness, and English Culture, 1830-1890 (New York: Pantheon, 1985). For a discussion of the effect of this phenomenon on the woman writer, see Sandra M. Gilbert and Susan Gubar, The Madwoman in the Attic: The Woman Writer and the Nineteenth-Century Literary Imagination (New Haven: Yale University Press, 1979), in particular the chapter "Infection in the Sentence: The Woman Writer and the Anxiety of Authorship," 45-92.

10. Barbara Ehrenreich and Deirdre English, Complaints and Disorders: The Sexual Politics of Sickness (Old Westbury, N.Y.: Feminist Press, 1973), 22. 
Ella somigliava un collegiale senza sesso, un piccolo ermafrodito vizioso: pallida, magra, con gli occhi avvivati dalla febbre e dal carbone, con la bocca troppo rossa, con i capelli corti, lanosi, un po' ricci, che le coprivano la testa a guisa d'un caschetto d'astrakan. Teneva incastrata nell'occhiaia sinistra una lente rotonda; portava un alto solino inamidato, la cravatta bianca, il panciotto aperto, una giacca nera di taglio maschile, una gardenia all'occhiello, affettando le maniere d'un dandy, parlando con una voce rauca. E attirava, tentava, per quella impronta di vizio, di depravazione, di mostruosità, ch'era nel suo aspetto, nelle sue attitudini, nelle sue parole. (Il piacere, 253)

[She resembled a sexless schoolboy, a vice-ridden little hermaphrodite: pale, thin, her eyes brightened by fever and kohl, her mouth too red. Her hair, short, woolly and slightly curled, covered her head like an astrachan helmet. She held a round lens tightly in her left eye. She wore a high starched collar, a white necktie, an open waiscoat, a black jacket of a masculine cut and a gardenia in her buttonhole. She affected the manners of a dandy and spoke with a husky voice. And she enticed, she tempted, precisely on account of that imprint of vice, depravity, and monstrosity in her appearance, her attitudes, and her words.]

Bébé Silva is a monstrosity precisely because she is a degraded embodiment of the "ideal androgyne." Along with her fellow demimondaines, she is the object in this episode of a facile misogyny that insists on "la dolce ignoranza di quelle belle oche" (Il piacere, 251) ["the sweet ignorance of those pretty geese"]. The young men are quite entertained by the women's inability to understand Latin and by their lack of historical knowledge. The narrator cannot be similarly faulted, as he demonstrates by reviving a topos as ancient as the Egyptian papyruses:

Quel vino chiaro e brillante, che ha su le donne una virtù così pronta e così strana, già incominciava ad eccitare variamente i cervelli e le matrici di quelle quattro etàire ineguali, a risvegliare e a stimolare in loro il piccolo dèmone isterico e a 
farlo correre per tutti i loro nervi propagando la follia. Bébé Silva gittava motti orribili, ridendo d'un riso soffocato e convulso e quasi singhiozzante come quel d'una donna che sia per morir di solletico. (Il piacere, 255)

[That light and sparkling wine which has such an immediate and such a strange effect upon women had already begun to excite, variously, the brains and wombs of those four unequal betairai, and to awaken and stimulate in them the little hysterical demon and cause it to run through their nerves, propagating madness. Bébé Silva tossed out horrible mottoes, laughing a suffocated, convulsed, almost sobbing laugh like that of a woman about to die from tickling.]

While the young men flaunt their knowledge of Latin, D'Annunzio shows off his knowledge of Greek. As though to alert the reader (whose Greek may be no better than Bébé Silva's Latin) that the hysteria of which he speaks is Hippocratic rather than Freudian (with an added touch from early Christian demonology), D'Annunzio prepares the ground by referring to the demimondaines, with the Greek term for courtesan, hetaira. His use of isterico is thus similarly Greek, referring specifically to the womb, hystera. D'Annunzio is both etymologically and medically exact in his revival of the topos of the "wandering womb." Wine was, in fact, thought to excite the uterine animal; in some cures wine was proscribed for a year in order to halt the womb's peregrinations. ${ }^{11}$ Bébé Silva's "hysterical fit" is precisely and etymologically that: convulsions resembling those of epilepsy and suffocation were the principal symptoms of a wandering womb. ${ }^{12}$

11. This cure appears in Aulus Cornelius Celsus's treatise "On Diseases of the Womb," where, according to Ilza Veith, "Celsus recommended that the therapy be extended an entire year in order to avoid recurrence and that wine be proscribed for the same length of time." Ilza Veith, Hysteria: The History of a Disease (Chicago: University of Chicago Press, 1965), 21.

12. Veith summarizes the Hippocratic text On the Diseases of Women in her history of hysteria: "The thinking ran that in such situations the uterus dries up and loses weight and, in its search for moisture, rises toward the hypochondrium, thus impeding the flow of breath which was supposed normally to descend into the abdominal cavity. If the organ comes to rest in this position it causes convulsions similar to those of epilepsy. If it mounts higher and attaches itself 
One might object that this is merely an archaic description of woman's physiology and not a description of a disease. Yet pathology is inherent in this description, and woman's physiology appears to be inseparable from pathology. Once begun, this fall into physiology acquires a momentum of its own and carries the text toward an equally pathological, if not equally ancient, topos, that of the enchantress turned hag:

Bébé Silva fumava, beveva bicchierini di vieux cognac e diceva cose enormi, con una vivacità artifiziale. Ma aveva a quando a quando, momenti di stanchezza, di prostrazione, stranissimi, ne' quali pareva che qualche cosa le cadesse dal volto e che nella sua figura sfrontata e oscena entrasse non so qual piccola figura triste, miserabile, malata, pensierosa, più vecchia della vecchiezza d'una bertuccia tisica che si ritragga in fondo alla sua gabbia a tossire dopo aver fatto ridere la gente. (Il piacere, 257)

[Bébé Silva smoked, drank tiny glasses of vieux cognac, and said outrageous things with an artificial vivacity. But from time to time she had the strangest moments of fatigue, of prostration, in which it seemed as though something fell from her face and into her brazen and obscene figure entered I don't know what sad, wretched, sick, pensive little figure, older than the old age of a consumptive monkey that withdraws to the corner of its cage to cough after having made people laugh.]

This topos functions as a moment of revelation: a reality concealed by artifice is unveiled. But what is the nature of the reality so

to the heart the patient feels anxiety and oppression and begins to vomit. When it fastens itself to the liver the patient loses her voice and grits her teeth, and her complexion turns ashen. If the uterus lodges in the loins, the woman feels a hard ball, or lump, in her side. But when it mounts as high as the head, it causes pains around the eyes and the nose, the head feels heavy, and drowsiness and lethargy set in. Beyond these specific symptoms, the movement of the womb generally produces palpitations and excessive perspiration and convulsions similar to those observed in epilepsy" (10-11). Hysteria was also thought of as suffocation of the womb, "suffocation of the Mother." 
revealed, and why is it figured as female? Canto 7 of Ariosto's Orlando furioso, in which the enchantress Alcina's magic is undone by Melissa, is undoubtedly an intertext to the D'Annunzian description and may begin to provide an answer:

Pallido, crespo e macilente avea Alcina il viso, il crin raro e canuto, sua statura a sei palmi non giungea: ogni dente di bocca era caduto; chè più d'Ecuba e più de la Cumea, ed avea più d'ogni altra mai vivuto. Ma sì l'arti usa al nostro tempo ignote, che bella e giovanetta parer puote.

Giovane e bella si fa con arte, sì che molti ingannò come Ruggiero; ma l'annel venne a interpretar le carte, che già molti anni avean celato il vero.

[She was whey-faced, wrinkled, and hollow-cheeked; her hair was white and sparse; she was not four feet high; the last tooth had dropped out of her jaw; she had lived longer than anyone on earth, longer than Hecuba or the Cumaean Sibyl. But she made such use of arts unknown in our day that she could pass for young and fair. Young and fair she made herself by artifice, and deceived many as she deceived Ruggiero. But now, with the ring, he could read the card aright and see the truth which for so many years had been kept hidden. ${ }^{13}$

The reality revealed by this commonplace is usually represented by an old, shrunken, toothless woman who is the bearer of disease or vermin. D'Annunzio eliminates toothlessness; Ariosto, disease. Machiavelli, in a 1509 letter to Luigi Guicciardini, eliminated neither and minced no words in elaborating upon the topos. The woman in question is not first described as beautiful and in the

13. Ludovico Ariosto, Orlando furioso, ed. Lanfranco Caretti (Milan: Ricciardi, 1954), 7.73.1-74.4; the translation is that of Guido Waldman (London: Oxford University Press, 1974), 69. 
flower of youth, though Machiavelli had clearly expected that she would be comely:

Venendomi pure voglia di vedere questa mercatanzia, tolsi un tizzone di fuoco d'un focolare, che v'era, ed accesi una lucerna, che vi era sopra. Nè prima el lume fu appreso, che 'l lume fu per cascarmi di mano. Omè fu' per cadere in terra morto, tanto era brutta quella femina. E' se le vedeva prima un ciuffo di capelli fra bianchi e neri, cioè canuticci, e, benchè l'avessi el cocuzzolo del capo calvo, per la cui calvizie a lo scoperto si vedeva passeggiare qualche pidocchio, nondimeno pochi capelli e rari le aggiugnevano con le barbe loro infino in su le ciglia. E nel mezzo della testa, piccola e grinzosa, aveva una margine di fuoco, chè la pareva bolata a la colonna di Mercato. In ogni punto delle ciglia di verso li occhi aveva un mazzetto di peli pieni di lendine; li occhi li aveva uno più basso ed uno alto; ed uno era maggiore che l'altro; piene le lagrimatoie di cispe ed e' nipitelli dipellicciati. El naso li era confitto sotto la testa, arricciato in su, e l'una delle nari tagliata, piena di mocci. La bocca somigliava quella di Lorenzo de' Medici, ma era torta da un lato, e da quella n'usciva un poco di bava, chè, per non aver denti, non poteva ritener le sciliva. Nel labbro di sopra aveva la barba lunghetta, ma rara. El mento aveva lungo, aguzzato, torto un poco in su; dal quale pendeva un poco di pelle, che le aggiungeva infino a la facella della gola. Stando attonito a mirar questo mostro, tutto smarrito, di che lei accortasi, volle dire: - Che avete voi messere? - Ma non lo disse, perchè era scilinguata. $\mathrm{E}$, come prima aperse la bocca, n'uscì un fiato sì puzzolente, che, trovandosi offesi da questa peste due porte di dua sdegnosissimi sensi, li occhi e il naso, e messi a tale sdegno, che lo stomaco, per non poter sopportare tale offesa, tutto si commosse. E, commosso, oprò sì che io le rece' addossi; e così, pagata di quella moneta che la meritava, mi partii.

[I had the urge to see my merchandise and I took a brand from the fireplace near me and lit a lamp that was above it; and hardly was it lit when the light almost dropped from my hand. My God! The woman was so ugly that I almost dropped 
dead. The first thing I noticed was a tuft of hair, half white and half black, and although the top of her head was bald, which allowed you to observe a number of lice taking a stroll, nevertheless a few hairs mingled with the whiskers that grew around her face; and on top of her small, wrinkled head there was a scar-burn which made her look as if she had been branded at the market; her eyebrows were full of nits; one eye looked down, the other up, and one was larger than the other. Her tear ducts were full of mucus and her eyelashes plucked; her nose was twisted into a funny shape, the nostrils were full of snot, and one of them was half cut off; her mouth looked like Lorenzo de' Medici's, but it was twisted on one side and drooled a bit since she had no teeth to keep the saliva in her mouth; her upper lip was covered with a thin but rather long moustache; her chin was long and sharp, pointed up, and from it hung a bit of skin that dangled to her Adam's apple. As I stood there, amazed at this monster, she noticed my surprise and tried to say: "What is the trouble, sir?"; but she could not, since she was a stutterer; and as she opened her mouth there came from it such such a stinking breath that my eyes and my nose, the two gateways of the two most outraged senses, found themselves offended by this pestilence; this was such a shock to my stomach that, not being able to bear it, it heaved so much that I vomited all over her. And so, having paid her in the way she deserved, I left. $]^{14}$

Machiavelli's description is certainly more Folenghian than Ariostean, but the basic outlines are the same. The old woman's hair is thin and whitish; her mouth, toothless. Virilization is part of uglification, just as it is an element of Bébé Silva's monstrosity; facial hair and (Machiavelli couldn't resist a stab at the Medici) a mouth that resembles Lorenzo's render her even more repulsive. It is striking that the description pans no lower than the woman's

14. Niccolò Machiavelli, "Spectabili viro L. Guicciardini in Mantova tanquam fratri carissimo," in Lettere, ed. Guiseppe Lesca (Florence: Rinascimento del Libro, 1929), 26-27, translated as "To Luigi Guicciardini in Mantua," in The Portable Machiavelli, ed. and trans. Peter Bondanella and Mark Musa (New York: Penguin, 1979), 59-60. 
throat; all emphasis is placed upon facial dissymmetry and, more important, upon various excretions from her facial orifices: "cispe," "mocci," "bava" ["mucus," "snot," "drool"]. Machiavelli's "due porte di dua sdegnosissimi sensi" ["two doors of two outraged senses"] are especially offended by the stinking breath that issues from this stuttering woman's mouth. These last details-stuttering and foul odor-send us to yet another such revelatory moment in which, however, a different "porta" is in question: the episode of "la femmina balba" in Purgatorio 19. Here there is a double movement from initial ugliness and deformation-

mi venne in sogno una femmina balba ne li occhi guercia, e sovra i piè distorta, con le man monche, e di colore scialba.

[There came to me in a dream a woman, stammering, with eyes asquint and crooked on her feet, with maimed hands, and of sallow hue.]

to enchantment, as she is transformed into a siren-

Poi ch'ell'avea 'l parlare così disciolto cominciava a cantar sì che con pena da lei avrei mio intento rivolto.

"Io son", cantava, "io son dolce serena che 'marinari in mezzo al mar dismago; tanto son di piacer a sentir piena!"

[When she had her speech thus unloosed, she began to sing so that it would have been hard for me to turn my attention from her. "I am," she sang, "I am the sweet Siren who leads mariners astray in mid-sea, so full am I of pleasantness to hear."]

and then to the moment of disenchantment, revelation, and revulsion- 
L'altra prendea e dinanzi apria fendendo i drappi, e mostravami 'l ventre; quel mi svegliò col puzzo che n'uscia.

[He seized the other and laid her bare in front, rending her garments and showing me her belly: this waked me with the stench that issued therefrom. $]^{15}$

Unveiling is here made literal ("fendendo i drappi") and the truth so revealed is a literalization of the "bocca sdentata" [toothless mouth] of the preceding descriptions. Emphasis on the mouth, breath, and facial excretions in Machiavelli's letter appears as a displacement upward of a horror that regards what D'Annunzio in Cento $e$ cento $e$ cento pagine calls "l'autre bouche" ["the other mouth"]. ${ }^{16}$ Such displacement facilitates a transfer between a "bocca sdentata" and a "vagina dentata." It is interesting, then, that D'Annunzio only includes a portion of the topos, omitting the toothless mouth. Such reticence is little more than a touch of delicacy in terms of our analysis of a text; by employing such a classic topos, he evokes the entire landscape that topos describes.

The topos of the enchantress turned hag is often read, by both critics and the writers themselves, as an attack not on women but on artifice in general and rhetoric in particular. As a figure for hermeneutics itself, it may be read as enacting the discovery of essence that lies beneath appearance, truth beneath falsehood, reality beneath fiction, plain speech beneath cosmetic rhetoric. Indeed, as we have seen, Nietzsche uses this very topos in order to overturn it, in order to critique the hermeneutic model that would find an essence beneath appearance. These are, of course, valid interpretations. Yet they discard the literal in order to concentrate on the figural and thus do not ask why woman is favored as the vehicle of the metaphor. What interests me here, however, is not only the

15. The edition used is Dante Alighieri, La commedia secondo l'antica vulgata, ed. Giorgio Petrocchi, 4 vols. (Milan: Mondadori, 1966-67), Purgatorio, 19.79, 16-21, 31-33; the translation is that of Charles Singleton, The Divine Comedy, with a commentary by Singleton (Princeton: Princeton University Press, 1973).

16. Gabriele D'Annunzio, Cento e cento e cento pagine del libro segreto di Gabriele D'Annunzio tentato di morire, in Prose di ricerca, Tutte le opere di Gabriele D'Annunzio, ed. Egidio Bianchetti (Milan: Mondadori, 1968), 2:754. 
tenor but also the vehicle, for in Il piacere we are dealing with a rhetoric of eros. The truth hidden by artifice is a double one: the truth concealed by Sperelli's rhetoric is a "truth" about woman's body, a truth that, as Machiavelli demonstrates, may be difficult to stomach.

When this topos appears in a discourse on eros, the figurative meaning sends us back to the literal meaning. Because it functions as an attack on artifice, the "truth" put forth disturbs the erotic effect of such discourse. The revelation unveils the "falsity" of Sperelli's rhetoric of uniqueness, for it uncovers a truth about woman's body, a "repulsive" common denominator shared by all women. Neither Elena nor Maria may now be L'Unica, nor can Sperelli be L'Unico:

L'impurità, che allora la fiamma alata dell'anima velava d'un velo sacro e circondava d'un mistero quasi divino, appariva ora senza il velo, senza il mistero della fiamma, come una lascivia interamente carnale, come una libidine bassa. Ed egli sentiva che quel suo ardore non era l'Amore e che non aveva più nulla di comune con l'Amore. Non era l'Amore. Ella gli aveva gridato: - Soffriresti tu di spartire con altri il mio corpo? -Ebbene, sì, egli l'avrebbe sofferto. (Il piacere, 261)

[The impurity that the winged flame of the soul had then veiled with a sacred veil and surrounded with an almost divine mystery, now appeared without the veil, without the mystery of the flame, as a wholly carnal lasciviousness, as a low lust. And he felt that this ardor of his was not Love, and no longer had anything in common with Love. It was not Love. She had cried: "Could you bear to share my body with others?" Well, yes, he would bear it.]

As the veils of Sperelli's rhetoric are rent, so too are the veils of Elena's charms; for the first time, she is described dispassionately:

La sua facoltà precipua, il suo asse intellettuale, per dir così, era l'imaginazione; un'imaginazione romantica, nudrita di letture diverse, direttamente dipendente dalla matrice, continuamente stimolata dall'isterismo. Possedendo una certa in- 
telligenza, essendo stata educata nel lusso d'una casa romana principesca, in quel lusso papale fatto di arte e di storia, ella erasi velata d'una vaga incipriatura estetica.... Ella copriva di framme eteree i bisogni erotici della sua carne e sapeva transformare in alto sentimento un basso appetito. (Il piacere, 268)

[Her principal faculty, her intellectual axis, so to speak, was imagination; a romantic imagination, nourished with wide reading, directly dependent upon her womb, constantly stimulated by hysteria. Possessed of a certain intelligence and brought up in the luxury of a princely Roman house, in that papal luxury made of art and history, she had veiled herself with a vague aesthetic cosmetic. . . . She covered the erotic needs of her flesh with ethereal flames and knew how to transform a low appetite into a noble sentiment.]

Under the framme eteree we find another etaira. Elena's veils are classier than Bébé Silva's, but like that of Bébé Silva and her companions, Elena's "incipriature estetica" is washed away in order to reveal both a psychological and a physiological truth about woman: her psychology is indistinguishable from her physiology, "direttamente dipendente dalla matrice." But if her psychology is determined by her physiology, and physiology (and physiological description) are, as D'Annunzio seems to suggest in these passages, inherently antierotic, then another solution must be found in order to perpetuate an eroticized erotic discourse. Sperelli discovers his solution by transforming the principle of interchangeability, only just discovered by drawing back the veils, into a new veil. He can eroticize his discourse and intercourse by superimposing an image of another woman upon the woman to whom he makes love:

Quella voce! Com'erano strani nella voce di Donna Maria gli accenti d'Elena! — Gli balenò un pensiero folle. - Quella voce poteva esser per lui l'elemento d'un'opera d'imaginazione: in virtù d'una tale affinità egli poteva fondere le due bellezze per possederne una terza imaginaria, più complessa, più perfetta, più vera perchè ideale. (Il piacere, 294) 
[That voice! How strange were Elena's tones in the voice of Donna Maria! A mad thought flashed before him. That voice could be the element of a work of the imagination for him: by virtue of such an affinity, he could combine their two beauties in order to possess a third, imaginary beauty, more complex, more perfect, more true because ideal.]

Though the result obtained appears truer, the strategy employed is still veiling. An image of one woman masks the physical reality of another; the technique is so effective that he takes the veil for reality when he calls Maria, Elena.

\section{Prometheus and Pandora}

"Egli non potrebbe credere al fallo di Giuliana." Were we to translate D'Annunzio's L'Innocente, this phrase might give us pause: He could not believe in Giuliana's offense? He could not believe in Giuliana's defect? He could not believe in Giuliana's . . . phallus? The pause might last but a moment, for surely we would cede to contextual pressure and choose the first of these versions: Tullio Hermil's brother, Federico, could not believe in Giuliana's error, in her offence, in her infidelity. We might rest assured that this, after all, is what the text means. But if we allow homonymy to speak, we find that the text asks questions of a different order: Could he believe in Giuliana's lack? Could he believe in Giuliana's phallus? Homonymy rends the text of L'Innocente, for fallo in Italian may mean all these things: error, mistake, or equivocation; a physical or spiritual defect, failing, or imperfection; a sin or offence; the emblem of the virile member or the organ itself. ${ }^{17}$ This particular case of homonymy opens dizzying possibilities for psychoanalytic discourse, for that which the woman lacks, il fallo, might be referred to by that very same term, fallo (her imperfection, her defect), and the recognition of this fallo (her failing, her defect) is itself the source of error and equivocation, yet another fallo.

17. Paolo Valesio first brought this homonym to my attention in a lecture "The Psychoanalysis of the Sword," Symposium on Sex and Language, New York City, 1 May 1981. 
Psychoanalysis would no longer be able to tell this particular story of haves and have-nots.

These possibilities, brought into view by the problem of translation, are not simply the result of a play upon the semantic richness and etymological difference of a homonym. Fallo is, in the text of L'Innocente, what Michael Riffaterre has called a dual sign, "an equivocal word situated at the point where two sequences of semantic or formal associations intersect. . . . These parallels meet, in defiance of geometric law, only because the dual sign properly placed in one of the two sequences would have been just as at home in the other." ${ }^{18}$ Privileged as dual signs are cases of homophony and, in particular, of homonymy. The dual sign may at first appear to be a pun, especially when, like paronomasia, it relies upon homophony. But while a pun's pungency is also based on homophony, its immediate context insists upon the transfer from homophony to synonymy. The pun in pungency, for example, is drawn out by its proximity to "pun"; the worse the pun (and "pungency" is a bad one), the more attention must be drawn to it by its context. A dual sign, instead, belongs simultaneously to two different texts: what Riffaterre has termed the mimetic, syntagmatic text, and the semiotic, paradigmatic text. Its "context-bound" syntagmatic meaning may well be "incompatible with the context-free paradigmatic significance." The dual appropriateness of the dual sign will be brought forth not by its immediate context, as in the case of a pun, but by an act of retroactive reading: "retroactive reading thus appears to be the method for decoding dual signs: first, because the sign refers to a paradigm, and a paradigm can be recognized

18. Michael Riffaterre, The Semiotics of Poetry (Bloomington: Indiana University Press, 1978), 86. One of Riffaterre's examples concerns the word oublie (a kind of wafer sold in the street) that, in a passage taken from Chateaubriand, appears in a funereal context such that its homophone, oubli, emerges in an "other text": "What is happening here is the overdetermination of the word oubli(e), doubly appropriate: it is generated by an associative chain of streetscene words, but also by a chain of mourning and death words" (88). Cynthia Chase analyzes another occurrence of this same dual sign, oublieloubli, in Rousseau's Neuvième promenade, in connection with Baudelaire's "abusive translation" of this sign into yet another dual sign, diligence, in "La morale du joujou." See her "Paragon, Parergon: Baudelaire Translates Rousseau," in Decomposing Figures: Rhetorical Readings in the Romantic Tradition (Baltimore: Johns Hopkins University Press, 1986), 196-208. 
only after it has been sufficiently developed in space so that certain constants can be perceived; second, because any stumbling block sends the reader scurrying back for a clue, back being the only place to go; third, because the correction made backwards via the proximate homologue creates the ghost or parallel text wherein the dual sign's second (or syntactically unacceptable) semantic allegiance can be vindicated." 19 Such a "ghost text" is precisely what we find in L'Innocente, for while the immediate, mimetic context forces us to read the syntactically acceptable "offence," the paradigmatic context allows us to read "phallus/failing." The ghost text to which these "secondary" associations belong is L'Innocente as an interpretation of the myth of Oedipus. The "secondary" fallothe failing, the phallus - is found at a crucial interpretive moment in this scrambled oedipal narrative.

As we have seen, a chiastic reversal takes place between the incipit and the second section, or second beginning. In the second section, Giuliana's infidelity is revealed and the narrative focuses not on Tullio's but on Giuliana's fallo and on the resultant pregnancy that becomes her "morbo." Giuliana's fallo, her sin, is inseparable from the fallo, the phallus:

Orbene, ella si dà a un uomo, commette il suo primo fallo, e rimane incinta, ignobilmente, con la facilità di quelle femmine calde che i villani sforzano dietro le siepi, su l'erba in tempo di foia. (L'Innocente, 517)

[So, she gives herself to a man, commits her first error (fallo) and gets pregnant, ignobly, with the ease of those hot females whom peasants rape behind bushes on the grass when they are in heat.]

This transfer of characteristics is, mimetically speaking, a transference of guilt: Tullio relinquishes his "imagine fallica" by projecting it onto Giuliana.

But Giuliana already had a fallo of a different sort. In the incipit, she too was afflicted by a "morbo ignoto," her vaguely diagnosed uterine dysfunction:

19. Riffaterre, 91. 
Seppi, dopo, che già da alcuni mesi la travagliavano malattie complicate della matrice e dell'ovaia, quelle terribili malattie nascoste che turbano in una donna tutte le funzioni della vita. (L'Innocente, 378)

[I later discovered that already for several months complicated diseases of the womb and the ovaries had tormented her, those terrible hidden diseases that disturb all the functions of life in woman.]

These terrifying hidden ills conveniently enough allow Tullio to avoid all erotic contact with Giuliana, and the discovery of them arrives almost as a wish fulfillment. One might expect these hidden ills to act as an antiaphrodisiac, to cause anxiety or disgust in Tullio. This is, in fact, the interpretation that is placed in the mouth of Giuliana:

- Di' - mi chiese un giorno, con la bocca amara-se tu ci pensi, non hai ribrezzo di me? Ah, che brutta cosa! E fece un atto di disgusto su sè medesima; e s'accigliò, e si ammutolì. (L'Innocente, 379)

["Tell me," she asked one day, her mouth full of bitterness, "if you think of it, are you repulsed by me? Oh what an ugly thing!" And she made a gesture of repugnance at herself, frowned and fell silent.

Her physician concurs and institutionalizes this presumed disgust by insisting that all erotic contact be avoided, thereby suggesting a purely naturalistic interpretation of both her malady and the prohibition it installs:

Il dottore, col quale volli avere un colloquio, mi fece intendere che per un lungo periodo io doveva rinunziare a qualunque contatto con la malata, anche alla più lieve delle carezze; e mi dichiarò che un nuovo parto avrebbe potuto esserle fatale. (L'Innocente, 378)

[The doctor with whom I insisted on speaking gave me to 
understand that I must renounce all contact, even the slightest of caresses, with the sick woman for some time. And he stated that another pregnancy might be fatal.]

Tullio himself, however, adds a prohibition of a different sort when he imagines the gynecological operation she must undergo. His description cuts to the heart of the matter, to the real nature of both terror and taboo, for this is no ordinary operation:

Ah, così mi parve, morente mi parve, quella mattina, quando i dottori l'addormentavano col cloroformio ed ella, sentendosi sprofondare nell'insensibilità della morte, due o tre volte tentò di alzare le braccia verso di me, tentò di chiamarmi. Io usciì dalla stanza, sconvolto; e intravidi i ferri chirurgici, una specie di cucchiaio tagliente, e la garza e il cotone e il ghiaccio e le altre cose preparate su un tavolo. Due lunghe ore, interminabili ore, aspettai, esacerbando la mia sofferenza con l'eccesso delle imaginazioni. E una disperata pietà strinse le mie viscere d'uomo, per quella creatura che i ferri del chirurgo violavano non soltanto nella carne miserabile ma nell'intimo dell'anima, nel sentimento più delicato che una donna possa custodire: una pietà per quella e per le altre, agitate da aspirazioni indefinite verso le idealità dell'amore, illuse dal sogno capzioso di cui il desiderio maschile le avvolge, smanianti d'inalzarsi, e così deboli, così malsane, così imperfette, uguagliate alle femmine brute dalle leggi inabolibili della Natura; che impone a loro il diritto della specie, sforza le loro matrici, le travaglia di morbi orrendi, le lascia esposte a tutte le degenerazioni. $\mathrm{E}$ in quella e nelle altre, rabbrividendo per ogni fibra, io vidi allora, con una lucidità spaventevole, vidi la piaga originale, la turpe ferita sempre aperta "che sanguina e che pute." (L'Innocente, 383)

[Dying! Oh, that is how she appeared to me that morning when the doctors put her to sleep with chloroform, and she, feeling herself sink into the insensibility of death, tried two or three times to lift her arms toward me, she tried to call me. I left the room, upset. And I glimpsed the surgical instruments, a sort of sharp spoon, and the gauze and the 
cotton and the ice and all the other things ready on a table. Two long, interminable hours I waited, exacerbating my suffering with an excess of fantasies. And in my male viscera I felt a pang of desperate pity for that creature whom the surgical instruments violated not only in her wretched flesh but in the recesses of her soul, in the most delicate sentiment that a woman can defend-a pity for her and for the others, tormented by indefinite aspirations toward the idealities of love, deluded by the captious dream with which masculine desire surrounds them, yearning to raise themselves up, and so weak, so sickly, so imperfect, made equal to the females of the brutes by the unabolishable laws of Nature, which imposes upon them the law of the species, strains their wombs, torments them with horrible maladies, leaves them exposed to all kinds of degeneration. And in that one, and in the others, shivering in every fiber, I saw then, with a frightening lucidity, I saw the original wound, the foul wound, always open, "that bleeds and stinks."]

The description marks above all a moment of revelation: what is hidden about the nature of her disease is revealed. The sight itself belongs to that "other" text within the text of L'Innocente, and is marked by the contrast between the (mimetic) "intravidi" and the (oneiric) "vidi...vidi." What Tullio sees is an interpretation of a perception: as he imagines the surgical operation, it becomes a repetition of a primal "operation" at the hand of nature: woman's castration. The foul wound that bleeds and stinks represents Giuliana's, and woman's ("in quella e nelle altre"), first fallo, her lack of a phallus. The sight of woman's wound is the sight of the Medusa, but though the narrator professes pity for these poor creatures, a pity that provokes a sympathetic reaction in his "viscere d'uomo," a fear that a similar fate might befall him remains implicit. ${ }^{20} \mathrm{He}$ is not frozen in fearful recognition but instead feels the stirrings of

20. For Freud, of course, the terror of Medusa is "a terror of castration that is linked to the sight of something," and that "something" is the woman's lack of a penis. See his "Medusa's Head," The Standard Edition of the Complete Psychological Works of Sigmund Freud, trans. James Strachey (1961; rpt. London: Hogarth Press, 1978), 18:273-74. 
a desire to repeat the scene of this operation, to reproduce its effects. The "memory" that, in the narrator's flow of associations, precedes and evokes Tullio's vision of the operation represents a desire to reeffect her castration in their intercourse:

La violenza del desiderio sarebbe in me attenuata dalla paura di farle male, di strapparle un grido di dolore. -Dopo tanto! - E i nostri esseri, all'urto di una sensazione divina e terribile, non provata nè imaginata mai, si struggerebbero. Ed ella, dopo, mi parebbe quasi morente, con la faccia tutta molle di pianto, pallida come il suo guanciale. Ah, così mi parve, morente mi parve, quella mattina. (L'Innocente, 383)

[The violence of my desire would be attenuated by the fear of hurting her, of drawing a cry of pain from her. "After so much!" And our beings, under the shock of a divine and terrible sensation, never before experienced or imagined, would melt. And afterwards, she would seem almost as though she were dying, with her face soft with tears and pale as her pillow. Ah, that is how she seemed, as though she were dying, that morning.]

The results of their lovemaking should mime the results of her operation. D'Annunzio did not, of course, invent the figuration of orgasm as death, but the immediate association of her "wound" and their lovemaking suggests a specific means of "dying." When this imagined scene moves from the conditional into the indicative, and Giuliana and Tullio rediscover passion at Villalilla, Giuliana's cries of "sono morta" ["I am dead"] act as a seductive prelude to their union.

There is, however, more to Hermil's fascination with Giuliana's "loss" than the desire for her repeated castration. Hermil, whose rhetoric is the accumulation of ever new sensations, suspects that Giuliana may have gained something else by having, as it were, nothing to lose:

La malattia, forse, aveva aumentata, esasperata quella sensibilità. Ed io pensai, curioso e perverso, che avrei veduto la debole vita della convalescente ardere e struggersi sotto la mia 
carezza; e pensai che la voluttà avrebbe avuto quasi un sapore d'incesto. "Se ella ne morisse?" pensai. Certe parole del chirurgo $\mathrm{mi}$ tornavano alla memoria, sinistre. E per quella crudeltà che è in fondo a tutti gli uomini sensuali, il pericolo non mi spaventò ma mi attrasse.(L'Innocente, 393)

[The illness had perhaps increased and exasperated her sensitivity. And curious and perverse, I thought that I would have seen the feeble life of the convalescent burn and melt beneath my caress. And I thought that the voluptuous pleasure would almost have a taste of incest. "If she were to die of it?" I thought. The surgeon's words returned to me, sinister. And because of that cruelty that lies at the base of all sensual men, the danger did not frighten me, but attracted me.]

Hermil's voluntary admission of sadistic impulses and incestuous yearnings might provide an adequate explanation of the aphrodisiac effect of Giuliana's illness and wound were it not that in the 1903 Laus vitae the wound "che sanguina e che pute" reappears. The body upon which it is inflicted is, however, no longer female:

Gli Efimeri onorano il càuto

Ribelle, oblioso del tuo

Ordine puro che solo generò l'Universo!

La piaga che sanguina e che pute

nell'egro fegato, sotto

il rostro del vùlture adunco,

ai lamentevoli figli

del Rimorso e della Paura

la piaga la piaga stridente

ahi più venerabile sembra

che la tua solitaria fronte

ove balzò l'unica nata

Pallade Atena dagli occhi

chiari vergine prode

artefice meditabonda

patrona dei vertici forti

nemica del cieco tumulto 


\author{
lucida regolatrice \\ del combattimento ordinato \\ che reca al sicuro trionfo! ${ }^{21}$
}

[The ephemeral ones worship the cautious Rebel, forgetful of your pure Order that alone generated the Universe! The wound that bleeds and stinks in the sick liver, under the hooked beak of the vulture, oh the wound, the strident wound seems more venerable to the lamentable sons of Remorse and of Fear than does your solitary brow whence bounded forth your only born, Pallas Athena of the bright eyes, the intrepid virgin, meditative artifex, patron of strong summits, enemy of blind tumult, lucid regulatrix of ordered combat that leads to certain triumph!]

The wound here described is that of cunning Prometheus, punished by Zeus for having stolen fire and given it to men. His, too, is a "piaga originale," for the Prometheus myth is also a myth of the origin of the "damnable race of women." Prometheus was only a part of his punishment; the other half was

21. Gabriele D'Annunzio, Maia, in Versi d'amore e di gloria, Tutte le opere di Gabriele D'Annunzio, ed. Egidio Bianchetti (Milan: Mondadori, 1950), 2:84.

22. Hesiod recounts Prometheus's story in both the Theogony and The Works and Days, placing little emphasis on the wound and accentuating instead the creation of Pandora as Prometheus's principal punishment. In the Theogony, Athena appears as accomplice to Zeus in the creation of Pandora: "In return for the theft of fire he instantly produced a curse to plague mankind. At the orders of the son of Cronus, the famous lame smith-god shaped some clay in the image of a tender girl. The bright-eyed goddess Athena dressed and decked her in silvery clothes. A marvelous embroidered veil fell from her head and was held in her hands. Round her head the goddess tied a golden diadem on which the smith-god himself had exercised his skill, to please his father Zeus. When Zeus had completed this beautiful curse to go with the blessing of fire, he displayed the girl in an assembly of gods and men, all decked out in the finery supplied by the bright-eyed daughter of the lord of hosts. Gods and men were speechless when they saw how deadly and irresistible was the trick with which Zeus was going to catch mankind. This was the origin of the damnable race of womena plague which men must live with." Hesiod, Theogony, ed. and trans. Norman O. Brown (Indianapolis: Bobbs-Merrill, 1953), 69-70. 
the gift of Pandora to men, a curse to accompany the blessing of fire. The image of Prometheus as midwife to the birth of women is reinforced by variations that figure him as instrumental to the birth of Athena; he is said to have struck Zeus's brow with an axe (thus causing another wound) at the propitious moment. ${ }^{23}$ D'Annunzio's omission of Pandora, of the creation of woman, is thus only apparent, for the abrupt comparison to Zeus's parturition of Athena serves the same symbolic function as would a mention of Pandora. Prometheus's wound is indissolubly linked with the origin of women; D'Annunzio's equation of Prometheus's and woman's wound suggests a reading of the Prometheus and Pandora myths such that Prometheus himself becomes woman, becomes Pandora. The symbolic, displaced castration of the myth is returned to its original site: it is Prometheus's wound that releases sickness and travail upon the human race:

\author{
L'odor della carne corrotta \\ del sudore anèlo, \\ della febbre, dell'agonia, \\ della putredine ha vinto \\ l'ambrosia della tua chioma \\ su' tuoi grandi pensieri \\ ondeggiante, o Generatore \\ incorruttibile. \\ (Maia, 84-85)
}

[The odor of corrupted flesh, of panting sweat, of fever and agony and putridity has conquered the ambrosia of your mane,

23. Apollodorus relates Zeus's "conception" and parturition of Athena: "From fear of that [that Metis should bear a son who would be lord of heaven] Zeus swallowed her. And when the time came for the birth to take place, Prometheus or, as others say, Hephaestus, smote the head of Zeus with an axe, and Athena, fully armed, leaped up from the top of his head at the river Triton." Apollodorus, The Library, trans. Sir James George Frazer (London: Heinemann, 1921), 25. For a survey of the many versions of the Prometheus myth, from Hesiod to Gide, see Jacqueline Duchemin, Prométhée: Histoire du mythe, de ses origines orientales à ses incarnations modernes (Paris: Société d'édition "Les belles lettres," 1974). 
undulating above your great thoughts, $\mathrm{O}$ incorruptible Generator.]

In the oldest version of the myth, Hesiod's Works and Days, this is precisely what Pandora releases from the vase she bears as a gift from Zeus to men. ${ }^{24}$ The description of Giuliana's wound in L'Innocente is faithful to this version, for her "piaga originale" is the matrix of "morbi orrendi" and "tutte le degenerazioni."

If Prometheus and Pandora are condensed into one figure, then we might say that Giuliana too is both a Prometheus and a Pandora. She is marked by a Promethean wound and bears the ills that plague mankind. The introduction of the myth of Prometheus suggests that access to knowledge is gained only at the price of woman's wound. That wound and its attendant illnesses are the price Prometheus must pay for his knowledge of the arts and of fire. ${ }^{25}$ It is as though woman herself were a figure for transgression and the knowledge gained thereby. But she possesses yet another of Prometheus's characteristics: though she is the bringer of degeneration, she also has, in her "wounded" organ, a capacity for continual regeneration. Just as Prometheus's liver grows back proportionately as it is eaten by the eagle, so do Giuliana's wounded

24. See Hesiod, The Works and Days, trans. Richmond Lattimore (Ann Arbor: University of Michigan Press, 1978), lines 90-102. The episode of the jar does not appear in the Theogony. In Pandora's Box: The Changing Aspects of a Mythical Symbol (New York: Pantheon, 1956), Dora and Erwin Panof sky trace to Erasmus the origin of Pandora's "box" as a mistranslation of the Greek pithos. It seems that only the Italian "vaso di Pandora" remains faithful to the original: "The only exception is, characteristically, Italy, less deeply committed to Erasmus than the transalpine world. Here the vernacular adhered, and adheres to this day, to 'vaso di Pandora,' and only the Latin-writing humanists-unless they were conscientious or pedantic enough to retain the orthodox 'dolium'inclined to yield to the Erasmian fashion, at least to the extent of reducing the size of the vessel to that of a 'vasculum'" (19). A part from Italy's relationship to Erasmus, however, there are lowlier reasons for such philological accuracy. If the vernacular continues to adhere to vaso, it is probably because la scatola di Pandora would have rather different connotations: le scatole refers to testicles.

25. According to Plato's Protagoras, Prometheus stole wisdom in the arts together with fire but not civic wisdom, which was in the possession of Zeus. See Plato, Laches, Protagoras, Meno, Euthydemus, trans. W. R. M. Lamb (London: William Heinemann, 1972), 320c-322d. 
organs "grow back" by producing a child. This connection between women's reproductive organs and Prometheus's wounded organ does not go unexplored in classical mythology. The story of Tityus "repeats" Prometheus's story, making explicit that which is already implicit in the myth, for Tityus's organ grew again with each new cycle of the moon; the regeneration of his organ thus follows the model of the menses. ${ }^{26}$ It is this regenerative ability, and the pregnancy that results from it, which is the source of Tullio's distress in the novel and, on at least one occasion, quite explicitly the source of his passion for Giuliana. Soon after learning of her pregnancy, Tullio makes violent love to her, hoping thereby to dislodge the developing fetus. It is as though he played the part of the eagle, reopening the "original wound." The desire to repeat her castration is grounded in a phantasy of continual regeneration of woman's fallo: woman is not castrated once and for all but, like Prometheus, wounded again and again. Hermil is caught in a reenactment, a repetition of the moment of discovery: again and again, the woman must regain her fallo in order to lose it; again and again, Hermil must castrate the woman in order to save his own fallo.

At this point, the dual sign fallo points us beyond the story of haves and have-nots to a different psychoanalytic tale of haves-whohave-not: fetishism. In his desire to repeat the moment of discovery, Hermil can be likened to Freud's fetishists who retain their belief that women have a phallus at the same time as they give up that belief. The fetish is, for Freud, the sign of the presence of something (specifically, of the mother's penis) and at the same time of its absence. The "subtlest" fetish accomplishes precisely this: Freud cites the case of a man whose fetish was a Schamgürtel, a "suspensory belt" that could be worn as either undergarment or bathing drawers and whose wearer could as easily have a male member as not have it, as easily be a have as a have-not. It thus suspended the decision between present and absent phallus, and the fetishist could simultaneously deny and accept the "fact" of woman's defect, of woman's

26. As punishment for having attempted to rape Leto, Tityus was stretched upon the ground "while two vultures or snakes ate his heart or liver, which grew again with each new cycle of the moon." See Edward Tripp, The Meridian Handbook of Classical Mytbology (New York: New American Library, 1970), 580. 
phallus, of woman's fallo: "Analysis showed that it signified that women were castrated, and that they were not castrated; and it also allowed of the hypothesis that men were castrated, for all these possibilities could equally well be concealed under the belt." 27 Hermil's phantasy of Promethean regeneration narrativizes the fetishist's divided attitude by turning the fetishist's simultaneous disavowal and affirmation of castration into sequential and infinitely repeatable moments.

But the similarities between fetishism and the text of L'Innocente are not limited to a thematic level, to a discussion of the mental process named by fetishism. They touch upon the process of signification as well: the dual sign fallo is itself a fetish on the level of language. Not only is fallo the sign of something's presence and of its absence, but like Freud's suspensory belt, it allows defect and phallus to coexist. Fallo is, linguistically, the perfect fetish, for when the word itself is read retroactively, it is equally at home in two texts: in the mimetic text of perception ("there is nothing there, no penis"), and the semiotic text of interpretation ("there must have been one, but now it is castrated"). At the same time it performs a metalinguistic function, for it names itself as equivocation, as fallo. Neither dual sign nor fetish (when understood as "suspensory belt") can be considered either a metaphor (as is assumed in common usage of the term fetish) or a metonymy (as in the cases Freud describes, where the last thing seen before the moment of discovery - shoes, pubic hair - then becomes the fetish) but both are, as Riffaterre says of the dual sign, "at once catachresis and the right word." 28 If catachresis is the "abuse of figure," a "metaphor" that does not substitute for a literal term (as in the "leg of a table" or the "eye of the storm"), then we might consider the woman's fallo to be a catachresis. Fallo is the woman's phallus: the penis she never had and yet was castrated, just as the "leg of the table" is the leg it never had and yet is lame, a "wooden leg." That is, just as there is no literal, proper way to say "leg" of the table, there is no literal way to say "penis of the woman"; and just as, in giving the table a leg, language mutilates it and ourselves, so in giving the woman a penis, woman-and man-is wounded,

27. See Freud, "Fetishism," Standard Edition, 21:156.

28. Riffaterre, 92. 
castrated. ${ }^{29}$ The table indeed has "something" that we call a leg (indeed, it is said to have a "head" as well), but naming it "leg" has amputated that leg from the body it does not have; woman has "something" yet that something is neither the presence nor the absence of a penis/phallus, but the equivocation named by fallo. Thus it is not so much the character Tullio who is fetishistic as the text itself, which creates such an undecidable fetish.

As in the case of the Oedipus myth, D'Annunzio's reading of castration is a scrambling of the Freudian code. It does not, I think, move outside of the possibilities foreseen in Freud's texts. Indeed, I have implied that the child is, in some sense, the woman's phallus just as Freud will claim that the woman's desire to have a child is a desire for the organ she lacks. What D'Annunzio's text suggests, however, is that the child-as-phallus provides a motive for infanticide on the part of the father.

But the story does not end here, for it is not only Giuliana who becomes both Prometheus and Pandora. The Prometheus-Pandora story is a powerful myth of transgression and its consequences,

29. See Andrzej Warminski's analysis of catachresis as self-mutilation in Readings in Interpretation: Hölderlin, Hegel, Heidegger (Minneapolis: University of Minnesota Press, 1987), liii-lxi. In Stanze: La parola e il fantasma nella cultura occidentale (Turin: Einaudi, 1977), Giorgio Agamben sees in the fetishist's Verleugnung the possibility of a model of signification no longer "under the sign of Oedipus," that is to say, no longer a hermeneutic scheme according to which metaphor (and meaning) is constituted by the substitution and exchange of improper and proper terms: "What the proper/improper schema prevents us from seeing is that in reality nothing is substituted for anything in metaphor, because there is no proper term that the metaphorical term is called to substitute: only our ancient oedipal prejudice-that is, an a posteriori interpretive schemamakes us see a substitution where there is only a dislocation within a single process of meaning [un unico significare]. . . . One can say, rather, that Verleugnung offers a model for the interpretation of metaphor that escapes from the traditional reduction of the problem, and in the light of that model metaphor becomes in the realm of language that which the fetish is in the realm of things. As in Verleugnung there is not in fact a 'transfer' ['trasporto'] from a proper or improper meaning" (177-78). At precisely this moment, when Agamben would like to propose a new linguistic model ("in the realm of language"), he has recourse to visual representations, to emblems and caricature, as examples and thus begs the question of language itself by amalgamating it to other semiotic systems. Catachresis might have served him better, since it is precisely in catachresis that the "proper/improper" schema is jettisoned. 
and thus it might easily be recuperated in the commonplace that D'Annunzio's erotic discourse is transgressive. The truth of that commonplace is irrefutable insofar as any erotic discourse is bound to set up prohibitions in order to transgress them. The question we must ask, then, is what law is being transgressed in D'Annunzio's text? Hermil's open admissions of incestuous desires, sadistic impulses, actual infanticide, and infidelity now appear to be misleading clues that tell us there is indeed a transgression, while throwing up a smoke screen that obscures the true nature of the transgression involved. Naturalistic explanations of woman's "sickness" as prohibition are also inadequate, for that disease is the contagion of castration.

The conflation of Prometheus and Pandora becomes, in fact, a powerful metaphor of the writer for whom eviration represents a desirable state. In both L'Innocente and Il piacere, scenes of the male protagonist's convalescence are preceded by scenes of dueling and therefore by the threat of a wound. Those convalescences are figured as conversions to aesthetic and moral values and are the scene of the protagonist's feminization. In Il piacere a rediscovery of the arts is specifically linked to Sperelli's wound; Sperelli is wounded in a duel at the close of book 1 and it is from this wound that he ostensibly convalesces. Hermil is not physically wounded, but instead meets his rival at a fencing club, assesses Arborio's skill as a fencer, and learns that he is to duel the following day. The narrative structure is the same in both cases: a scene of dueling ends the opening section and prepares the ground for the protagonist's feminization and convalescence. Hermil's feminization occurs by less direct means when, in the two succeeding chapters he takes on Giuliana's role and qualities as a "spiritual" convalescent. But Tullio, too, is metaphorically wounded, for his conversion to goodness is contingent upon his separation from Teresa Raffo, the "imagine fallica" that had led him astray. In order to gain pardon, he must expiate his sin: "Lo so, lo so; tutti i miei dolori non valgono forse il tuo dolore, non valgono le tue lagrime. Io non ho espiato il mio fallo, e non sono degno d'essere perdonato" (L'Innocente, 449) ["I know, I know; all my sufferings are not equal to your suffering, are not equal to your tears. I have not expiated my sin/phallus [fallo] and I am not worthy of being forgiven"]. Once again, 
homonymy rends the text, for Tullio must expiate both sin and phallus.

The feminization undergone by both male protagonists remains an indirect eviration rather than castration. Physiological description, assiduously avoided, reappears instead as a description of organic disturbance not in the "viscere d'uomo" but in "la matrice femminile." The most female of ills is chosen to figure the most male of fears; Giuliana's sickness, her vaguely diagnosed uterine dysfunction, thus appears as a displacement of Tullio's "castration."

Hermil professes to desire sadistically the castration of the other, yet his own feminization suggests that he might also identify with this "castrated" being, as he does during what is presented as Giuliana's second surgical operation, childbirth: "Soffrivo anch'io uno strazio fisico, simile forse a quello d'un'amputazione mal praticata e lentissima. Gli urli della partoriente mi giungevano a traverso l'uscio" (L'Innocente, 578) [“I, too, suffered physical torture, perhaps similar to that of a clumsy and very slow amputation. The screams of the woman giving birth reached me from across the threshold"]. This comparison of childbirth to an amputation undergone by the protagonist points once again to the transference of a fantasy of castration onto Giuliana. Giuliana is more desirable following this "amputation," just as she had become desirable after her first operation. Giuliana becomes the castrated, wounded being Tullio desires, and desires to be; the feminized Tullio's desire for her is thus almost a desire for his own castration in her. Here lies Tullio's true transgression, for he too would become both Prometheus and Pandora.

\section{A Sacred Disease}

Trionfo della morte continues and enlarges upon themes from $\mathrm{Il}$ piacere and L'Innocente. Sperelli's preoccupation with finding "L'Unica" becomes Giorgio Aurispa's obsession, while Tullio Hermil's obsession with paternity becomes Aurispa's dread and desire. The rhetoric of female sickness embodies both concerns in this, the final novel of the trilogy, where the dominant moment is that of flight from the flesh and revulsion at the moment of revelation. 
Aurispa's goal is total possession of his lover: "C'è su la terra una sola ebrezza durevole; la sicurtà nel possesso di un'altra creatura, la sicurtà assoluta incrollabile. Io cerco questa ebrezza" (Trionfo, 796) ["There is only one lasting intoxication on earth: certainty in the possession of another creature, absolute, unshakable certainty"]. The major obstacle to such possession is not the uncertainty of the present or future, but the irrevocability of the past. The first two sections, "Il passato" and "La casa paterna," represent this obstacle and establish the themes of priority and fatherhood which will dominate in the novel. Those themes, according to Harold Bloom, are the preoccupations of the poet. In his analysis of the relationship between poet and muse, Bloom observes that the desire for the one-and-only woman and the poet's attitude toward his muse appear to be similarly motivated:

If he himself is not to be victimized, then the strong poet must "rescue" the beloved Muse from his precursors. Of course, he "overestimates" the Muse, seeing her as unique and irreplaceable, for how else can he be assured that be is unique and irreplaceable? Freud dryly remarks that "the pressing desire in the unconscious for some irreplaceable thing often resolves itself into an endless series in actuality," a pattern particularly prevalent in the love life of most poets, or perhaps of all postRomantic men and women cursed with strong imagination. ${ }^{30}$

The desire to be unique raises the problem of priority, for possession of the muse-or of mortal women-can only be complete if the poet is her "first": "If this is to serve as a model for the family romance between poets, it needs to be transformed, so as to place the emphasis less upon phallic fatherhood, and more upon priority, for the commodity in which poets deal, their authority, their property, turns upon priority."

These two aspects of the family romance, phallic fatherhood and priority, are precisely Aurispa's concerns. Yet he can achieve neither, and Ippolita's illnesses come to represent the impossibility

30. Harold Bloom, The Anxiety of Influence: A Theory of Poetry (1973; rpt. London: Oxford University Press, 1981), 63.

31. Ibid., 61. 
of possession and priority in erotic matters. Ippolita is afflicted with both "il dèmone isterico" ["the hysterical demon"] and "il male sacro" ["the sacred ill"], diseases that appear as the continuing presence of the past in her body, and which figure her prior possession by others.

Like Elena and Giuliana, Ippolita is governed by "il dèmone isterico." But here uterine ills take on yet another meaning, for Ippolita's "malattia della matrice" appears as as the record of her previous sexual experience. Her prior possesion is recorded in a peculiarly female sort of memory:

"Una tale donna" egli pensava "è stata d'altri prima che mia! Ha giaciuto con un altro uomo; ha dormito con un altro uomo nel medesimo letto, sul medesimo guanciale. In tutte le donne è singolarmente viva una specie di memoria fisica, la memoria delle sensazioni." (Trionfo, 830)

["A woman like this," he thought, "has belonged to others before she was mine! She has lain with another man; she has slept with another man in the same bed, on the same pillow. In all women a sort of physical memory, the memory of sensations, is singularly alive."]

Woman's physiological memory manifests itself as disease, for the origin of her malady is traced to her marriage and sexual initiation:

Ippolita era andata a nozze nella primavera avanti quella dell'amore. Dopo alcune settimane le era incominciata la malattia della matrice, lenta e crudele, che, riducendola in fondo a un letto, l'aveva tenuta per molti giorni sospesa tra la vita e la morte. Ma la malattia per fortuna l'aveva salvata da qualunque altro contatto odioso con l'uomo che s'era impadronito di lei, come d'una preda inerte. (Trionfo, 830)

[Ippolita had been married the spring before their love. After several months, the disease of the womb had begun, slow and cruel. It had confined her to her bed and for many days held her suspended between life and death. But fortunately the 
disease saved her from any further contact with the man who had taken possession of her, as of an inert prey.]

If her ailment is a welcome obstacle to further relations with her husband, it is also an obstacle to her jouissance with Aurispa. Though Ippolita claims to be a sort of emotional virgin, not having yet experienced the "voluttà dell'amore," her "isteralgia" appears to be inseparable from the memory of her loss of virginity:

Ma a poco a poco, di giorno in giorno, una sensibilità latente aveva incominciato a risvegliarsi nelle fibre di lei intorpidite dal morbo, ancóra addolorate dagli spasimi dell'isteralgia, ancóra forse dominate da un istinto ostile contro un atto già parso odioso nelle orribili notti nuziali. (Trionfo, 831)

[But little by little, day by day, a latent sensitivity had begun to awaken in her fibers numbed by the malady and perhaps still in pain from the spasms of hysteralgia, still dominated by an instinct hostile to an act that had previously, in those horrible nuptial nights, seemed odious to her.]

It is as though Ippolita's physiological memory were indelibly implanted in her body. The memory seems to have been obliterated when, following her introduction to the "voluttà dell'amore," Ippolita appears to have undergone a transformation and become "another" woman. Yet respite is temporary, for that physiological memory contains not only her sexual initiation but her social origins as well. Her beauty is contaminated by both sexuality and her petit bourgeois roots:

Non erano belli i piedi nudi ch'ella a volta a volta scaldava su la ghiaia e rinfrescava nell'acqua; erano anzi difformati nelle dita, plebei, senz'alcuna finezza; avevano l'impronta manifesta della bassa stirpe. Egli li guardava intentamente; non guardava se non quelli, con uno straordinario acume di percezione e di esame, come se le particolarità della forma dovessero rivelargli un segreto. E pensava: "Quante cose fermentano nel suo sangue! Tutti gli istinti ereditarii della sua razza sono in lei, 
indistruttibili, pronti a svilupparsi ed ad insorgere contro qualunque constrizione." (Trionfo, 941)

[Her bare feet, which by turns she warmed on the gravel and cooled in the water, were not beautiful; rather, the toes were deformed and plebeian, without any refinement. They bore the clear imprint of low origins. He stared at them intently; he watched only them, with an extraordinary sharpness of perception and of examination, as though the peculiarities of their form would reveal a secret to him. And he thought: "How many things ferment in her blood! All the hereditary instincts of her race are in her, indestructible, ready to develop and rise up against every restraint."]

Such a biological memory is precisely what Aurispa fears, not so much in Ippolita as in himself, for it is his own heredity that is perceived as inscribed in Ippolita's body. It is this genetic fatalism, rather than merely Ippolita's sterility, which leads him to renounce the perpetuation of both his own life and life in general. Death triumphs in this novel because the flight from the flesh is total; Aurispa flees not only from the "flesh" of the sexual act but from his own flesh and blood.

Though Aurispa's insistence upon Ippolita's sterility suggests that he wishes to become a father, his descriptions of his own flesh and blood point to a more fundamental problem: how to become a father without becoming his own father. Only Aurispa's mother is exempt from the "germi ereditati dal padre" ["germs inherited from the father"]; his Aunt Gioconda with her typhoid breath, his sister Cristina and her sickly child, his brother Diego, and even his uncle Demetrio, dead by his own hand to avoid a worse fateall seem to be contaminated by a hereditary fault:

Il suo pensiero, la sua attenzione andarono al padre, con un passaggio spontaneo. Diego era il vero erede di quell'uomo.

Pingue, sanguigno, possente, quell'uomo pareva emanare dalle sue membra un perpetuo calore di vitalità carnale. Le mascelle assai grosse; la bocca tumida e imperiosa, piena d'un soffio veemente; gli occhi torbidi e un po' biechi; il naso grande, palpitante, sparso di rossore; tutte le linee del volto 
portavano l'impronta della violenza e della durezza. Ogni gesto, ogni attitudine aveva l'impeto d'uno sforzo, come se la musculatura di quel gran corpo fosse in lotta continua con l'adipe ingombrante. La carne, la carne, questa cosa bruta, piena di vene, di nervi, di tendini, di glandule, d'ossa, piena di istinti e di bisogni; la carne che suda e che dà lezzo; la carne che si difforma, che s'ammala, che si piaga, che si copre di calli, di grinze, di pustole, di porri, di peli; questa cosa bruta, la carne prosperava in quell'uomo con una specie di impudenza, dando al delicato vicino una impressione quasi di ribrezzo. "Non era, non era così, dieci, quindici anni fa; non era cosi" pensava Giorgio. "Io ricordo bene che non era. Sembra che questa espansione d'una brutalità latente, insospettata, si sia compiuta in lui a poco a poco. Io, io sono il figliuolo di quest'uomo!" (Trionfo, 737)

[His thought and attention shifted to his father, in a spontaneous transition. Diego was truly that man's heir.

Fat, sanguine, powerful, that man seemed to exude from his members a perpetual warmth of carnal vitality. His jaws were heavy, his mouth tumid and imperious, full of a vehement breath, his eyes were turbid and sinister. His nose was large, palpitating, reddish; all the lines of his face bore the imprint of violence and toughness. Every gesture and attitude had the impetus of an effort, as if the musculature of that large body were locked in a continual struggle with its encumbrance of fat. The flesh, the flesh, this brute thing full of veins, nerves, tendons, glands, bones, full of instincts and needs, the flesh that sweats and stinks, the flesh that deforms and sickens and is wounded and covered with callouses, with wrinkles and pustules and warts and hairs, this brute thing flesh prospered in that man with a sort of impudence and gave an impression of revulsion to his refined neighbor. "No, he wasn't like this ten, fifteen years ago, he wasn't like this," thought Giorgio. "I remember well that he was not like this. It seems that this expansion of latent and unsuspected brutality has occurred little by little. And I, I am this man's son!"] 
This vision of the father's flesh as the flourishing of disease is later magnified into the sanctuary scene, in which all imaginable illnesses and deformations of humankind are presented not as a projection of the father but as Ippolita's dream, as the unleashing of Pandora's box. As the transposition from the father to Ippolita suggests, this vision deeroticizes the flesh of the sexual act and motivates the most radical and irreparable unveiling of the Romanzi della Rosa:

“Ah la solitudine, la libertà, l'amore senza vicinanza, l'amore per le donne morte o inaccessibili!" La presenza d'Ippolita gli impediva qualunque oblio; gli richiamava sempre l'imagine del congiungimento bestiale, della copula operata con gli organi escrementizii, dell'at to spasmodico sterile e triste ch'era omai divenuto l'unica manifestazione del loro amore. (Trionfo, 983)

["Ah solitude, freedom, love without closeness, love for dead or inaccessible women!" The presence of Ippolita obstructed forgetfulness; it always recalled the image of bestial conjunction, of the copula accomplished with the excremental organs, of the spasmodic, sterile, and sad act that had become the only manifestation of their love.]

Once the topos of "inter urinas et faeces nascimur" has been evoked ("gli organi escrementizii"), there is little salvation possible for an erotic discourse that speaks of the female body as the source of eroticism.

Yet even if Aurispa's genes were clean and Ippolita had come to him a virgin, Aurispa's desire for total possession could never be satisfied. Ippolita is afflicted by a sacred disease, epilepsy:

Un terribile male, già da lei sofferto nell'infanzia, un male nervoso che aveva le forme dell'epilessia, era di nuovo apparso. Le lettere, con la data di agosto, ne parlavano. "Tu non imaginerai giammai lo sbigottimento ch'io ho nello spirito. La mia tortura maggiore è questa implacabile lucidezza della visione fantastica. Io ti vedo contorcerti, nell'accesso; io vedo i tuoi lineamenti scomporsi e illividirsi, i tuoi occhi volgersi disperatamente sotto le palpebre rosse di pianto... Io vedo 
tutta la terribilità del male, come s'io ti fossi vicino..." (Trionfo, 710 )

[A terrible ailment, which she had already suffered as a child, a nervous ailment that took the form of epilepsy, had appeared again. His letters, dated in August, spoke of it. "You can never imagine the fear that I have in my soul. My greatest torment is this implacable lucidity of imaginative vision. I see you writhing during the attack; I see your face become distorted and livid, your eyes roll desperately beneath their lids, red from crying... I see all the horror of your illness as though I were near to you..."]

The voyeuristic emphasis in this passage suggests that her convulsions are a parody of her ecstasy in love. And yet though this first mention of her disease appears to eroticize it, her epilepsy acquires quite different connotations after the sanctuary scene. In the tale of "La vergine Anna" epilepsy was never referred to as "il male sacro," but here D'Annunzio quite explicitly indicates that Ippolita suffers from a sacred ailment. At the end of the sanctuary scene, Aurispa is tormented by the recent vision of an epileptic, a vision he cannot separate from Ippolita:

Appariva e spariva il fantasma, quasi fosse il sogno della dormente, esternato e reso visibile. "S'ella si risvegliasse e in lei il male sacro?" pensava Giorgio, con un brivido intimo. "L'imagine che si forma nel mio cervello m'è forse trasmessa da lei." (Trionfo, 918)

[The phantasm appeared and disappeared, as though it were the dream of the sleeper, externalized and made visible. "If she should awaken and, with her, the sacred disease?" thought Giorgio, with an inner shiver. "This image that takes shape in my brain has perhaps been transmitted from her to me."]

As sacred (and demonic), epilepsy is a disease of possession, and so appears to figure the impossibility of any true priority, any total possession. The woman is already possessed, already of another. The attribution of epilepsy to Ippolita is a recognition of the 
insurmountable obstacles to the possession of the beloved; so it is that the novel must end with a murder-suicide, as Aurispa pushes and then accompanies Ippolita over a cliff. The solution the novel offers to the problem of priority is culmination: the decadent lover, like the decadent writer, chooses to be the end of a line rather than accept the impossibility of priority.

\section{A Memorial to Medusa}

Bellezza meduséa, la bellezza dei romantici intrisa di pena, di corruzione, e di morte. La ritroveremo alla fine del secolo quando la vedremo illuminarsi del sorriso della Gioconda. (Mario Praz)

The final unveiling of Trionfo della morte puts an end to the rhetoric of physiological sickness which characterizes D'Annunzio's early prose works. Thereafter it will be the fetishist's disavowal that will prevail, and erotic discourse in his later works will elaborate upon the fetishistic strategy of L'Innocente. Though a full exploration of his later works lies beyond the scope - and intentof this book, a final example of such a strategy will illuminate not only D'Annunzio's "evolution" but the consequences of the decadent's occupation of the woman's body.

As we have seen, fetishism names not simply an obsession with certain objects (as assumed in common parlance) but a particular logic that allows contradictory beliefs-affirmation and disavowal of castration-to coexist. ${ }^{32}$ The sign of both presence and absence, the Freudian fetish may, in the patient's experience, be determined

32. As referring to a mode of signification, the term fetishism has been applied to situations that may or may not refer to castration. Giorgio Agamben, for example, argues that the Marxian "fetishism of commodities" is based on a similar logic: "And just as the fetishist never succeeds in completely possessing his fetish, because it is the sign of two contradictory realities, so the owner of a commodity can never enjoy it simultaneously as use-value and as exchangevalue" (45). Derrida's "generalized fetishism" would include Hegelian Aufbebung and the "virgin mother" of Christianity. See Jacques Derrida, Glas (Paris: Galilée, 1974), and Gayatri Spivak's discussion of Glas in "Displacement and the Discourse of Woman," Displacement: Derrida and After, ed. Mark Krupnick (Bloomington: Indiana University Press, 1983), 169-95. 
by metonymy, the last thing seen before the moment of "revelation" being a likely choice. But what happens when the fetish enters the literary text? Something that might be considered a fetish from a thematic point of view-a collection of cut-off braids, an obsession with feet-might not enter the economy of the text in the sense outlined here. Giorgio Agamben has suggested, in response to this problem, that a particular rhetorical figure, synecdoche, might be said to participate in the logic of fetishism:

It is curious to observe how a mental process of a fetishistic sort is implicit in one of the tropes common to poetic language: synecdoche (and also in its close relative [nella sua parente prossima], metonymy). To the substitution of part for whole that it effects (or of an object contiguous to another) corresponds the substitution of a part of the body (or of a related object) to the complete sexual partner in fetishism. That this is not simply a superficial analogy is borne out by the fact that metonymic substitution does not exhaust itself in the pure and simple surrogation of one term for another; the substituted term is instead at once negated and evoked by its substitute in a procedure whose ambiguity closely recalls Freudian Verleugnung. ${ }^{33}$

Agamben's suggestion that synecdoche at once evokes and negates the "whole" for which it stands, that the presence of the "part" is the sign of the absence of the whole, is tantalizing but perhaps too totalizing. Are all synecdoches then fetishistic? Would a thematic obsession with feet or a collection of braids then necessarily hint at a fetishistic logic at the same time as it appeared in the text as a synecdoche for the whole, the body, of which it is a part?

In traditional rhetoric, of course, synecdoche names the figure in which the part stands for the whole (pars pro toto, or vice versa, totum proparte), the part refers to the whole. In the case of fetishism, however, the status of the "whole" to which the "part" refers must be taken into consideration. When we say "all hands on deck," the hands stand for sailors in a way different from the way in which the fetish stands "for" the woman's (and ultimately the mother's)

33. Agamben, 40 . 
penis. In his extension of the notion of fetishism, Agamben seems to "forget" castration: the fetish comes to substitute the "partner sessuale completo," rather than the "woman's penis," and femininity is displaced instead onto metomymy, "sua parente prossima." The logic of fetishism thus becomes simply a way of "having one's cake and eating it too," of having the thing and its negation. But there is no "cake" to be had: the fetish itself does not stand for the woman's penis, does not refer to it, but rather stands in "its" place of absence just as a catachresis stands in the place of something for which there is no "proper" term. As Sarah Kofman reminds us, there is no "thing" to which the fetish refers:

The mother's penis, the "thing itself," is always already a fetish invented by the child, a belief implying at once denial and affirmation of castration. There was never a "thing itself," but only ersatz, a sham, a prosthesis, an originary supplementarity as the panicked reaction of infantile narcissism. Adult fetishism is a repetition of this spontaneous infantile fetishism and is not a substitute for the "thing itself" or for truth; as substitute for the phantasmal penis of the mother, it always already implies the play of supplementary difference in the "thing itself."

Thus if synecdoche is to be privileged as the trope of fetishism, it must be a synecdoche that cannot be made to refer to a "whole," to the thing itself, but only to other synecdoches, pars pro parte. It must, in other words, be a catacbrestic synecdoche that puts "something" in the place of "nothing." 35

Now, of all the "parts" that litter D'Annunzio's texts, none is more pervasive and eroticized (or more subject to a description as

34. Sarah Kofman, "Ça cloche," in Lectures de Derrida (Paris: Galilée, 1984), 136-37.

35. That the relation of part to whole is put into question by the castration complex is confirmed by Jean Laplanche, in Problématiques II: Castration/Symbolisations (Paris: Presses Universitaires de France, 1980): "One may then ask: in this severance that is castration, what is severed from what? By this I mean: if one cuts between the penis and the individual, which is the principal and which is the accessory? . . Where is the subject in castration? . . . On the side of the castrated body, or rather on the side of that which is cut, the penis?" (25). 
fetish in common parlance) than the hand. ${ }^{36}$ Whiter than white, smoother than marble, the hand seems to stand for the woman. These hands would be just another exhibit in D'Annunzio's collection of precious objects and bric-a-brac were it not that this particular synecdoche is the basis for a narrative of mutilation in the drama La Gioconda. This narrative, in which synecdoche appears as mutilation, as catachrestic synecdoche, participates in and constructs the logic of fetishism.

The plot seems rather banal at first: a sculptor, convalescent after a suicide attempt, is still torn between his faithful, loving wife and a femme fatale, "La Gioconda." The choice between two women is an ethical choice between a life in art, "fuori delle leggi e fuori dei diritti umani" ["outside of laws and outside of human rights"], and a life of "domestic virtues." The two women confront each other. The desperate wife resorts to a lie, and tells the femme fatale that her husband no longer wishes to see her. Beside herself, the rival attempts to destroy the wondrously beautiful statue she had inspired. The wife attempts to save the statue, which, in its fall, severs her hands. She interprets her amputation as punishment for her falsehood; the husband returns to art and the femme fatale while the wife remains husbandless and handless. And banal it would remain-yet another fin-de-siècle variation on the immunity of aesthetics to ethics, framed by a mannered elaboration of Walter Pater's celebration of Da Vinci's enigmatic portrait-had the play ended here. ${ }^{37}$ But the drama continues with a fourth act in which neither sculptor nor muse is present; there is only the amputee, and the scene of a child's discovery that her mother has no hands.

36. See for example Glauco Viazzi's catalogue of D'Annunzian hands in "Di alcune funzioni segniche e corrispondenze nelle Vergini delle rocce," ES: Materiali per il '900 (June-August 1980): 29. Viazzi's notion of fetishism is precisely of the "common parlance" variety, and he does not include Silvia Settala's severed hands in his collection.

37. Pater's influential essay "Leonardo da Vinci" first appeared in the Fortnightly Review (November 1869). See Walter Pater, The Renaissance, ed. Donald L. Hill (Berkeley: University of California Press, 1980), 77-101. The prominence given the hands sculpted by Verrocchio in D'Annunzio's play can be read as homage to the prominence granted Verrocchio's sketch in Pater's essay. See Praz, Romantic Agony, for a survey of variations on the theme of La Gioconda. 
It is above all this "excessive" fourth act that sends us back to reread the play as a mise-en-scène of the fetishist's Verleugnung.

This (almost comical) tragedy is about nothing if not hands and the rule of catachrestic synecdoche. Dedicated to Eleonora Duse "dalle belle mani" ["of the beautiful hands"], the play is somewhat mechanical in its composition, as though an assignment had been given a precocious schoolboy to write a theme on "hands." The mechanicity could be described in various ways: as the mechanicity of the writer's hand, as the mechanicity of the hand of destiny, as the mechanicity of catachrestic synecdoche that must continually refer only to other synecdoches. Set in a room that seems "ordinato dalle mani di una Grazia pensierosa" ["ordered by the hands of a pensive Grace"], ${ }^{38}$ the tragedy of Lucio Settala, the sculptor who has "nelle sue mani una vita di fiamma" ["a life of flame in his hands"], and Silvia Settala, whose "care, care mani, coraggiose e belle . . . sono d'una straordinaria bellezza" ["dear, dear hands, courageous and beautiful . . . are of extraordinary beauty"] unfolds. Lucio participates in the now-familiar narrative of convalescence: his attempt to take his life by his own hand ("Con la mano medesima che aveva impresso della creta il segno di vita, con la mano medesima egli strinse l'arma e la rivolse contro il suo cuore" [309] ["With the very hand that had imprinted the sign of life in clay, with that very hand he had held the weapon and turned it against his heart"]) left him wounded, and his convalescence has taken on the appearance of a conversion. He appears reborn, childlike ("Sembra ch'egli rinasca. Dianzi aveva gli occhi d'un bambino" [233] ["He seems to be reborn. Just now he had the eyes of a child"]), and converted from the life of aesthetics to that of ethics. He receives his new life from the hands of his wife: "Io benedico la sera e l'ora che mi portarono moribondo in questa casa del tuo martirio e della tua fede per ricevere un'altra volta dalle tue manida queste divine mani che tremano-il dono della vita" (262) ["I bless the evening and the hour that they brought me, dying, to this house of your martyrdom and your faith to receive once again

38. Gabriele D'Annunzio, La Gioconda, in Tragedie, sogni e misteri, Tutte le opere di Gabriele D'Annunzio, ed. Egidio Bianchetti (Milan: Mondadori, 1964), $1: 234$. 
from your hands - from these divine hands that tremble- the gift of life"]. It is hoped that the life so transmitted will flow into Lucio's hands, and Lorenzo Gaddi suggests a method by which the transfer might be effected: "Quando Lucio riprenderà il suo lavoro, dovrà il primo giorno modellare le vostre mani. Io ho un pezzo di marmo antico, trovato negli Orti Oricellari. Glie lo darò, perché le scolpisca in quello e poi le sospenda come un ex-voto" (239) ["When Lucio takes up his work again, he ought to model your hands the first day. I have a piece of ancient marble, found in the Oricellari Gardens. I will give it to him, that he might sculpt your hands in it and hang it up as a votive offering"]. Such marble hands, however, already exist in the text in the form of a copy of a Verrocchio bust, indicated as one of the few props in the scene. Silvia's hands are "of the same essence" as those of the bust:

Sono perfette. Ricordate la donna del Verrocchio, la Donna dal mazzolino, quella dai capelli a grappoli? Ah, è là. . . . Voi avete dunque già riconosciuto la parentela. Quelle due mani sembrano consanguinee delle vostre, sono della medesima essenza. Vivono, è vero? d'una vita così luminosa che il resto della figura n'è oscurato. (La Gioconda, 239)

[They are perfect. Remember the woman by Verrocchio, the woman with the bunch of flowers, the one with her hair in clusters? Ah, it is there. . . . Then you have already recognized the relationship. Those two hands seem of the same blood as yours, they are of the same essence. They are alive, aren't they, with a life so luminous that they overshadow the rest of the figure.]

The portrait bust is itself a synecdoche: it is not a representation of a woman amputated from the waist down, but evokes the body of which it is the partial representation. Here the hands have taken on a life of their own, displacing the "whole" of which they are "part." But that "whole" is itself a part, and the hands are a synecdoche of synecdoche. The text seems to have entered into a spiraling mise en abîme in which one synecdoche displaces another: the gift of life passes from Silvia's hands to Lucio's hands to sculpted hands to Silvia's hands. The catalogue could continue, one pair of 
hands replacing another, one synecdoche handed over for another in a metaphorical relay.

The turns in the spiral trace the outlines of a reverse Pygmalion narrative. Silvia is on her way to becoming a statue, and her hands, already of the same essence as sculpted hands, will be the first to go. Though Lucio Settala himself will not mold her with bis very own hands, he can be seen as an anti-Pygmalion. His desire is not to breathe life into his statues, not to give them a soul: "Io non scolpisco le anime" (274) ["I do not sculpt souls"], he says, expressing his aesthetic indifference to his wife's moral strength. This antiethical stance of the aesthete is hardly the sorrowful lament of a Pygmalion who longs for a soul for his creation, and it is Lucio's aesthetic ideal that will determine the kind of statue Silvia will become.

Lucio Settala's pseudo-Nietzschean aspiration to a realm beyond good and evil gives us no concrete idea of what that sculpted ideal might be, and there is, in fact, no direct description of his dazzling statue. Both the scene in which Silvia sees the statue for the first time and that in which she breaks the statue's fall take place behind a red curtain, offstage. It seems that she can be seen only obliquely, through allusive memory and feverish vision. Here the stage directions, never subordinate to dialogue in D'Annunzio's plays, are revealing. The entry to Lucio's studio is guarded by two Nikes, the Nike of Samothrace and the Paionios Nike, by fragments from the Panathenaic frieze, the bas-relief of Demeter from the Eleusis museum, the Ludovisian Medusa, and a small bronze Pegasus. It would seem that Lucio's ideal is Greek. But the "analogie di tutte le forme" ["analogies of all the forms"] go beyond those of antiquity and nationality: all except the Pegasus are fragments. The Nike of Samothrace is armless and headless; the Nike of Paionios handless, faceless, and wingless; the Panathenaic fragments are fragments of fragments; the bas-relief, a fragment; the Medusa, beheaded. The Pegasus, though presumably "whole," belongs to the series as a product of mutilation, born from the blood that sprang from the the Medusa's decapitation. The trait shared by all is mutilation. Lucio's aesthetic ideal is Greek, but "Greek" is here understood not as harmonius whole but as mutilated part. ${ }^{39}$ If one considers

39. Though Maria Teresa Marabini-Moevs does not specifically address the 
these fragments synecdoches, then according to Agamben's reasoning, they are already fetishistic and would negate the whole of which they were part as much as they evoke that whole. ${ }^{40}$ Indeed, Greek art is known to us primarily as an art of fragments, of "mutilations" and "synecdoches" that are presumably parts of a once extant whole. We might say that it is difficult, if not impossible, to decide whether the aesthetic value of Greek sculpture-as mutilated fragment - can be accounted for by appealing to the imagined whole of which it is presumably a fragment, or whether their value does not lie instead in their mutilation. But the truly fetishistic quality of such fragments only emerges if we put in doubt the "whole" and ask: what if the Greeks only sculpted mutilated fragments to begin with? This seems to be the question posed by the text's refusal to represent the sculptor's "finished product." As we have noted, Lucio's own wondrously beautiful statue is never "seen"

grouping of these sculptures in La Gioconda, she suggests that the "analogy" that links them is not that of fragmentation but of adherent drapery, "that kind of drapery conventionally called bagnato." Maria Teresa Marabini-Moevs, Gabriele D'Annunzio e le estetiche della fine del secolo (L'Aquila: L. V. Japadre, 1976), 222. This emphasis on drapery follows the standard art-historical description of these sculptures. That D'Annunzio was indeed appreciative of the clinging drapery is attested by the section of the Taccuini where he describes a statue of Victory by Paionios in the Acropolis Museum: "Il lungo peplo dorico disegna le forme nettamente come se fosse umido e aderisse alle membra vive. Tutto il marmo, se bene mutilato, è meraviglioso di audacia, di eleganza e di verità." Taccuini, Tutte le opere di Gabriele D'Annunzio, ed. Enrica Bianchetti (Verona: Mondadori, 1976), 53. ["The long Doric peplum traces the forms clearly as though it were damp and adhered to living members. Though mutilated, the marble statue is a marvel of audacity, elegance and truth."] Even here, however, mutilation appears as one of the statue's qualities, and it is above all the presence of a Medusa in La Gioconda that shifts the focus of the analogy. Read from the perspective of the 1898 tragedy, the 1895 annotations seem already to contain the (Greek) inspiration for La Gioconda: "la mano mutilata di Deidamia" ["the mutilated hand of Deidemia"] (53); "A destra del dio sta il re Enomaio, di cui non rimane se non il busto gagliardo e la testa mutilata" ["To the right of the god stands king Ennommus, of whom remains only a hearty bust and mutilated head"] (51); "Il braccio destro, che è monco, levava forse un grappolo. Dai ginocchi in giù mancano le gambe. . . . dei due piedi uno solo fu ritrovato" ["The right arm, which is handless, perhaps raised a bunch of grapes. The legs are missing from the knees down. . . . only one of two feet was found"] (50).

40. Though Agamben does suggest that fragments in general are fetishistic, he does not speak of Greek sculpture in particular. 
in the text, but we do learn that it is a sphinx. According to the logic I have described, however, it is more "Greek" than Egyptian for its beauty lies in its mutilation: "imperiosa e pura che porta le ali imprigionate vive negli omeri" " "imperious and pure, with wings imprisoned alive in its shoulders"] it vividly recalls the "pesante mostro senza ali" ["heavy wingless monster"] that was its model. Lucio sculpts mutilations - a fact that does not bode well for Silvia, whose beautiful hands seem to be wings: "Sembra da qualche giorno che abbia le ali. . . . Sì, ella è veramente quali i vostri occhi di sorella la vedono. Esce dal suo martirio alata" (244) ["For several days now, it seems that she has wings. . . . Yes, she is truly as your sisterly eyes see her. She has emerged from martyrdom winged"]. Silvia emerged from martyrdom like a winged victory, but only mutilation can make her "Greek." statue are mutilated by its fall: she emerges handless, and her sister gathers up the severed hands to wrap them in the dampened cloth that had covered the clay statue; the statue emerges armless: "Così sul piedistallo sembra veramente un marmo antico, disseppellito in una delle Cicladi" (334) ["On the pedestal like that, it truly looks like an ancient marble, unearthed in one of the Cyclades"].

The fourth act reverses the reverse Pygmalion narrative of the first three acts: transformed into a "Greek" statue, the handless Silvia, "la mutilata," speaks. But this double reversal of the Pygmalion narrative is no longer Pygmalion at all, but instead its "consequence": the Medusan moment predicted by an earlier poem in the Poema paradisiaco. ${ }^{42}$ The fourth act brings together a thematics of mutilation with what we might call a certain rhetorical destiny. Indeed, the inevitability of Silvia's fate, of her mutilation and petrification, is already inscribed in the poem, "Le mani" ["Hands"], an exercise in synecdoche in which the image of "la

41. Silvia's transformation into a wingless victory has been noted by Armand Caraccio: "Throughout the fourth act, Silvia Settala will carry her poor painful stumps like a wingless Victory, like a 'mutilated Victory'-whence the title of the trilogy." See Armand Caraccio, D'Annunzio dramaturge (Paris: Presses Universitaires de France, 1950), 75.

42. "In terms of mythological exempla," writes John Freccero, "petrification by the Medusa is the real consequence of Pygmalion's folly." See John Freccero, "Medusa: The Letter and the Spirit," Dante: The Poetics of Conversion (Cambridge: Harvard University Press, 1986), 130. 
mutilata" first appears. A cataloguing of women's hands sets in motion the mutilation intrinsic to catachrestic synecdoche and culminates in a parenthetical, oneiric vision:

(Nel sogno sta la mutilata, e attira.

Nel sogno immobilmente eretta vive l'atroce donna da le mani mozze.

$E$ innanzi a lei rosseggiano due pozze di sangue, e le mani entro ancòra vive sonvi, neppure d'una stilla sozze. $)^{43}$

[In dream stands the mutilated one, and attracts. In dream immobily erect lives the atrocious woman with amputated hands. And before her two pools of blood glow red, and the hands therein are still alive, sullied by not even a drop of blood.]

A parenthesis may qualify, explain, or be in apposition to the syntactic construction it interrupts; here the "interruption" appears to be an explanation and unfolding of the rhetorical figure upon which the poem plays. What appears as an aside is in fact central to the poem, for it is a literalization of that figure. If the part stands for the whole in synecdoche, here the part(s) stand quite literally before the (mutilated) whole. Like the hands of the Verrocchio bust, they have taken on a life of their own ("ancòra vive"). All the other hands in the poem are, by analogy, similarly severed. It is not coincidental, then, that the lines immediately preceding the parenthesis describe alabastrine hands as "più possenti di qualunque spira":

Altre (o le stesse?), mani alabastrine ma più possenti di qualunque spira, ci diedero un furor geloso, un'ira folle; e pensammo di mozzarle al fine.

43. Gabriele D'Annunzio, "Le mani," Poema paradisiaco, in Versi d'amore e di gloria, 1:684. 
[Others (or the same?), alabastrine hands, but more powerful than any coil, gave us a jealous furor, a mad ire; and we thought of cutting them off at the end.]

These hands provoke a "furor geloso, un'ira folle" and a desire to cut them off. The "spira," a coil of snakes, brings to mind the Medusa's coiffure; the atrocious woman's attraction ("sta . . . e attira), the Medusa's apotropaic power to fascinate and repel; her stance ("immobilmente eretta"), the petrification of the observer. ${ }^{44}$ The parenthesis is thus the fulfillment of this desire and, by separating the "mutilata" from the rest of the poem, iconically mimes the separation of part from whole. That is to say, the parenthesis exhibits in its own structure the very structure it describes.

The final, supplementary act of La Gioconda occupies this same parenthetical, oneiric space created in "Le mani." Considered thematically, the narrative can be said to move from cause to effect, from Silvia's "sin" (another fallo?) to her punishment. From that point of view the final act appears excessive, "tacked on," as it were. From the point of view of fetishism, however, that narrative can be said to move from effect to cause, from the fetishization of hands to the "source" of the fetish. From this second point of view, the final act logically (in the logic of fetishism) precedes the first three acts, for it enacts a discovery of "mutilation." Like his reading of Oedipus, D'Annunzio's reading of Medusa is a scrambling of the Freudian code. For Freud of course, the terror of Medusa is "a terror of castration that is linked to the sight of something." final scene of La Gioconda is about nothing if not the "sight of something" and that something is, as in Freud, perceived as an absence. In both cases, that "sight of something" is the sight of "nothing"; in this sense, neither is at odds with the false etymology of the Medusa's name as "mé idòsan, quod videre non possit" ["that which cannot be seen"]. ${ }^{46}$ For Freud that absence is the woman's genitals or, more precisely, the "mother's penis"; the something that is seen is seen as a negative and in that sense "cannot be seen." For D'Annunzio, that absence is the "mother's hands," an absence

44. See Freud "Medusa's Head," 273-74.

45. Ibid., 273.

46. Noted in Freccero, 124. 
that is hidden on stage and therefore cannot be seen. "La mutilata" is also "la castrata."

The scene plays upon the presence or absence of hands, upon the pathos of the twice-repeated disclosure of her mutilation, first to the childlike "La Sirenetta" and then to her daughter. While the first three acts focused on Silvia in her relation to Lucio, that is as wife, the final act focuses on Silvia in relation to Beata, that is as mother, as mother with something missing. A long-sleeved robe conceals her stumps, her clipped wings, but cannot conceal that there is something "lacking": "V'è nella sua movenza qualche cosa di manchevole, che suscita un'imagine vaga d'ali tarpate, che dà il sentimento vago d'una forza umiliata e tronca, d'una nobiltà avvilita, d'una armonia rotta." (La Gioconda, 316) ["There is something lacking in her movement; it calls up a vague image of clipped wings and creates a vague sense of a humiliated and truncated strength, of nobility brought low, of a broken harmony"]. Though Freud himself does not explicitly mention the Medusa in his essay on fetishism, her presence is implicit precisely as the horror of "qualche cosa di manchevole" which produces the fetishist's disavowal: "What happened, therefore, is that the boy refused to take cognizance of the fact of his having perceived that a woman does not have a penis. No, that could not be true. . . . the horror of castration has set up a memorial to itself in the creation of this substitute." 47 The fetish is thus a "memorial" dedicated to Medusa. The scenario of discovery and denial described by Freud is strikingly similar to the scene that takes place between Silvia and La Sirenetta:

Silvia Settala: Non le ho più.

La Sirenetta: Non le hai più! Te le hanno tagliate? Sei monca? No, no, no! Non è vero. Dimmi che non è vero.

Silvia Settala: Non le ho più.

La Sirenettta: Perché? perché?

Silvia Settala: Non dimandare!

(La Gioconda, 325)

[Silvia Settala: I don't have them anymore.

47. Freud, "Fetishism," 153-54. 
La Sirenetta: You don't have them anymore? Have they cut them off? No hands? No, no, no! It isn't true. Tell me that it isn't true.

Silvia Settala: I don't have them anymore.

La Sirenetta: Why? Why?

Silvia Settala: Don't ask!]

La Sirenetta, of course, does not become a fetishist as a result of her discovery, though she does reevoke the presence of her hands in a nostalgic catalogue of their former functions ("me ne ricordo: le vedo, le vedo" [325]) ["I remember them, I see them, I see them"]. As in the case of fallo, what occurs here is not a matter of a character who creates a fetish but rather of the text itself that creates a fetish effect by setting up a tension between a multiplication of hands and their absence. The scene is filled with reminders so blatant as to seem fingers pointing to her lack: the Verrocchio bust, "le cui belle mani sono pur sempre intatte" ["whose beautiful hands are still intact"], is once again present in the set description, as is a spinet, "strumento abbandonato" ["abandoned instrument"]. La Sirenetta offers Silvia a five-fingered starfish, "più grande di una mano" ["larger than a hand"], whose regenerative ability contrasts almost sadistically with Silvia's condition. The presence of hands pointing to the absence of hands is riveting (one could imagine that, when the play is staged, the audience would fasten its attention upon the long sleeves, eager to catch a glimpse of the absence of hands). The proliferation of such reminders can be compared to Medusa's serpentine hair, for Freud suggests that it is the "multiplication of penis symbols (that) signifies castration" and mitigates the horror of discovery. ${ }^{48}$ Already in Freud's recuperation of these snakes as "mitigation," the logic of fetishism is at work, suggesting that Medusa's head itself is a fetish. ${ }^{49}$ The sight of something that is a sight of nothing is already a fetishistic moment.

48. Freud, "Medusa's Head," 273.

49. Bernard Pautrat suggests that Medusa's head can be read as the extreme example of a fetish in which castration is almost completely recognized: "Medusa's head is thus entirely paradoxical. At once an image of castration (open mouth, eyes popping out of their sockets [regard exorbité]) and multiplied image of the threatened penis. . . . It is a very paradoxical figuration, since the Medusa carries on her face at once castration and its denial. . . . Medusa's head 
The final act maintains a suspension between proliferation and absence by refusing to represent Beata's - the daughter's-recognition of her mother's mutilation. The scene, and hence the play, ends with the reunion of mother and daughter after months of separation caused by Silvia's convalescence. Beata brings flowers, which her mother cannot grasp, and expects caresses, which her mother cannot give. ${ }^{50}$

La voce di Beata: Mamma! Mamma! Mamma!

Silvia Settala: Beata! Beata!

Beata: Ah, quanto ho corso, quanto ho corso! Sono fuggita, sola. Ho corso, ho corso ... Non volevano lasciarmi venire. Ah, ma io sono fuggita, col mio fascio di fiori.

Silvia Settala: Sei tutta molle di sudore, sei tutta calda, bruci ... Mio Dio!

Beata: Perché non mi prendi? Perché non mi stringi?

Prendimi! Prendimi, mamma!

Silvia Settala: Beata!

Beata: Non vuoi? Non vuoi?

Silvia Settala: Beata!

Beata: Tu giochi? Che nascondi? Oh, dammi, dammi quello che nascondi!

Silvia Settala: Beata! Beata!

Beata: Io t'ho portato i fiori, tanti fiori. Vedi? Vedi? Oh, la Sirenetta! Sei là? Vedi quanti? Tutti per te! Tieni!

Silvia Settala: Beata! Beata!

Beata: Non li vuoi? Prendi! Tieni!

faithfully obeys this logic of the fetish: simply, in it, reality outweighs desire; it is the recognition of castration that overwhelmingly dominates the denial; it is the absence of the penis being read before the fiction of its presence. If one were to read Medusa's head as a fetish, it would be the extreme example of a fetish in which castration is almost absolutely recognized and nevertheless immediately compensated for, obliterated by several substitutes: snakes, the head itself erected like a sun against the night of the abyss." See his "Nietzsche Médusé," Nietzsche aujourd'bui? (Paris: Union Générale d'Editions, 1973), 1:2627.

50. The offering of flowers, of course, recalls once again the Verrocchio bust The Lady with a Bunch of Flowers. 
Silvia Settala: Beata!

Beata: Piangi? Piangi?

(La Gioconda, 336-39)

[Beata's voice: Mama! Mama! Mama!

Silvia Settala: Beata! Beata!

Beata: Oh, how I ran, how I ran! I ran off, all alone. I ran, I ran. They didn't want to let me come. Oh, but I ran away, with my bunch of flowers.

Silvia Settala: You are all damp with sweat, you are hot, burning ... Oh God!

Beata: Why don't you pick me up? Why don't you hug me? Pick me up, pick me up, Mama!

Silvia Settala: Beata!

Beata: Don't you want to? Don't you want to?

Silvia Settala: Beata!

Beata: Are you playing? What are you hiding? Oh, give me, give me what you are hiding!

Silvia Settala: Beata! Beata!

Beata: I brought you flowers, so many flowers! Do you see?

See? Oh, Sirenetta! Are you there? See how many! All for you! Take them!

Silvia Settala: Beata! Beata!

Beata: Don't you want them? Take them! Take them!

Silvia Settala: Beata!

Beata: Are you crying? Are you crying?]

Silvia cannot give Beata what she hides, nor can the play end with Silvia raising her arms so that her stumps are revealed. Such a revelation would put an end to the fetishist's oscillation and lead to a direct recognition of "castration." displaced, and fetishistic revelation: this second disclosure is a

51. See Kofman, "Ça cloche," especially 132-39, and the text upon which she comments, Derrida, Glas. See also Elizabeth Berg's review of Kofman, "The Third Woman," Diacritics 12 (1982):11-20, and Naomi Schor, "Female Fetishism: The Case of George Sand," in The Female Body in Western Culture: Contemporary Approaches, ed. Susan Suleiman (Cambridge: Harvard University Press, 1986), 363-72. 
disclosure manqué. Thematically it describes the reunion of mother and child. Rhetorically, however, the final scene is a series of repetitions of single words and groups of words known as geminatio, a figure that, according to Heinrich Lausberg, is an emphatic expression of separation between people. ${ }^{52}$ Mother and child are thus separated in their moment of reunion. It is not too farfetched to see in their separation a repetition of the earlier separation of part from whole. Such an interpretation is made possible not by a ideology that sees the child as part of the mother but by reading between the lines. It is literally between the lines, in the stage directions, that the amputation is reenacted: Silvia falls to her knees before her daughter and "un fiotto di pianto, che sgorga dagli occhi come il sangue da una ferita, le inonda la faccia" (339) ["a flood of tears, which burst from her eyes like blood from a wound, bathes her face"]. It is as though her wound were reopened, the hands severed again. But what we "see" is not the wound itself but the hands: in the final sentence of the play, hands once again appear on the ground before Silvia: "La Sirenetta, caduta anch'ella in ginocchio, prona, tocca con la fronte e con le palme distese la terra" (339) ["La Sirenetta, who has also fallen to her knees, prone, touches the earth with her forehead and with the palms of her hands spread wide"]. Just as Giuliana's "wound" was continually reopened, so must Silvia regain her hands in order to lose them again. The metaphorical relay in which one synecdoche is handed over for another is thus perpetuated, and must be perpetuated; the fetishistic synecdoche does not "refer" to a whole, to the thing itself, but only to other synecdoches. The text is caught in a loop and can only turn back upon itself: it must execute the same series

52. See Heinrich Lausberg, Elemente der literarischen Rhetorik (Munich: Max Hueber, 1963), par. 248: "Geminatio at the end [of a sentence] occurs as the insistent expression of spatial separation between people." Lanham's example of geminatio is equally appropriate: "O horror, horror, horror!" Lanham does not mention separation in his definition and cites only the repetition of the word borror, without including the context from which it is drawn. That context, however, is Macduffs reaction to the discovery of Duncan's murder in Macbeth (2.3.76-78), a sight compared to that of the Gorgon. See Richard Lanham, $A$ Handlist of Rhetorical Terms (Berkeley: University of California Press, 1969), 46. It should be noted that Silvia says nothing other than "Beata." This repetition of her child's name, "blessed one," thus seems to take on a hortatory force as though the mother were blessing her child: "May you be blessed!" 
of commands with no hope of exit, for only the Medusa's memorials can be seen, never the Medusa herself.

Indeed, once this mechanism has been revealed, we can reread the text and discover other memorials to Medusa. All, including Gioconda Dianti, are under the rule of synecdoche and participate in the Medusan moment that is this Pygmalion's lot. Like her namesake, La Gioconda's whole is in fact a "part"; just as the Mona Lisa's smile has taken on a life of its own, obscured the rest of the painting, so La Gioconda's gaze has taken over her "whole":

La vita degli occhi è lo sguardo, questa cosa indicibile, più espressiva d'ogni parola, d'ogni suono, infinitamente profonda e pure istantanea come il baleno, più rapida ancora del baleno, innumerevole, onnipossente: insomma lo sguardo. Ora imagina diffusa su tutto il corpo di lei la vita dello sguardo. . . . Imagina questo mistero su tutto il suo corpo! Imagina per tutte le sue membra dalla fronte al tallone, questo apparire di vite fulminee! Potrai tu scolpire lo sguardo? Gli antichi accecarono le statue. Ora-imagina-tutto il corpo di lei è come lo sguardo. . . . Te l'ho detto: mille statue, non una. La sua bellezza vive in tutti i marmi. (274-75)

[The life of the eyes is the gaze, this unspeakable thing, more expressive than any word, than any sound, infinitely profound and yet instantaneous as a flash, even swifter than a flash, innumerable, omnipotent: in a word, the gaze. Now imagine the life of the gaze diffused all over her body. . . . Imagine this mystery over all her body! Imagine over all her limbs from her forehead to her heel this lightning flash of lives! Could you sculpt that gaze? The ancients blinded their statues. Now, imagine, her entire body is like the gaze. . . . I have told you: a thousand statues, not one. Her beauty lives in all marbles.]

La Gioconda's beauty is dazzling; the multiplication of the gaze ("questa cosa . . . innumerevole") not only recalls the multiplication of hands in the final act and the multiplication of serpents on Medusa's head but evokes a "blinding" at its center: "Gli antichi accecarono le statue." La Gioconda is already a blinding and blinded 
statue. ${ }^{53}$ Indeed, La Gioconda's attraction is a stony one; when Lucio sees her, he sees marble: "Quando mi apparve l'altra, io pensai a tutti i blocchi di marmo contenuti nelle cave delle montagne lontane" (274) ["When the other woman appeared to me, I thought of all the blocks of marble contained in the caves of the

53. This description of La Gioconda parallels, not coincidentally, Rilke's description of the "Archaïscher Torso Apollos" in the Neue Gedichte. That Rilke knew the play is made evident by his writings on Rodin, where he alludes to Eleonora Duse's portrayal of Silvia in La Gioconda. This mention appears precisely in the context of a discussion of sculpture (Rodin's La méditation) and of "mutilation" as aesthetic ideal: "The arms are noticeably absent. Rodin felt them in this instance to be something extraneous to the body, which sought to be its own concealment, without external aid. One recalls Duse, how in one of D'Annunzio's plays, when left bitterly alone, she attempts to give an armless embrace, to hold without hands. This scene, in which her body learns a caress far beyond its natural scope, belongs to the unforgettable moments of her acting. It conveyed the impression that arms were a superfluous adornment, something for the rich and self-indulgent, something which those in the pursuit of poverty could easily cast aside. She looked in that moment not like a person lacking something important; but rather like someone who has given away his cup that he may drink from the stream itself, like someone who is naked and a little helpless in his absolute nakedness. The same effect is produced by the armless statues of Rodin; nothing essential is lacking. We stand before them as before something whole and complete, which allows of no addition. The feeling of incompleteness does not come from the mere aspect of a thing, but is due to elaborate reflexion, to petty pedantry, which says that where there is a body there must be arms, that a body without arms can, in no instance, be complete." The "petty pedantry" Rilke so eloquently describes is precisely the logic of Freud's infantile theorists of sexuality: where there is a body there must be a penis, and a body without a penis can, in no instance, be complete. Rilke's comparison of the Duse to Rodin's armless statues not only supports the argument that Silvia is turned into a statue, but puts into question the (synecdochal) relation of part to whole. Thus the "mutilated whole" becomes the harmonious, complete whole, while the severed "part" itself becomes another whole: "The artist has the right to make one thing out of many and a world out of the smallest part of a thing. Rodin has made hands, independent, small hands which, without forming part of a body are yet alive. Hands rising upright, angry and irritated, hands whose five bristling fingers seem to bark like the five throats of a Cerberus. Hands in motion, sleeping hands and hands in the act of awaking; criminal hands, weighted by heredity, hands that are tired and have lost all desire, lying like some sick beast crouched in a corner, knowing none can help them. . . . Hands have a history of their own, they have, indeed, their own civilization, their special beauty; we concede to them the right to have their own development, their own wishes, feelings, moods and favourite occupations." Rainer Maria 
distant mountains"]. Her dazzling effect is similar to that of Lucio's feverish vision of his own creation:

Nella prima febbre quando avevo ancòra il piombo nella carne e il rombo continuo della morte su l'anima perdita, la vedevo dritta a pié del letto, accesa come una torcia, come se io medesimo l'avessi plasmata in una materia incandescendente. (252)

[In the first fever when I still had the lead in my flesh and the continous rumble of death on my lost soul, I saw her erect at the foot of my bed, lit like a torch, as though I myself had molded her in incandescent matter.]

In his convalescence, he has lost the vision of his fiery statue and suggests that his reaction to seeing it again would be horror: "Non la vedo più. Mi sfugge. Appare e dispare come in un baleno, confusa. Se l'avessi ora qui davanti, mi parrebbe nuova; gitterei un grido" (251-52) ["I see her no longer. She escapes me. She appears and disappears as though in a flash, confused. If I had her here before me now, she would seem new; I would scream"]. The analogy between La Gioconda and Lucio's statue, with its juxtaposition of La Gioconda as all eyes and the statue as that which is unseen, offstage, ab-scena, and hence (etymologically) obscene, seems to be yet another memorial to Medusa. Lucio is surrounded by Medusas; no wonder then that, in the last mention of him in the play, he seems to have worked himself into a frenzy:

Il suo viso è così scarno che sembra debba divorarglielo il fuoco dagli occhi. Quando parla, si eccita stranamente. Ne rimasi turbato. Lavora, lavora, lavora, con una terribile furia: forse cerca di sottrarsi a un pensiero che lo rode. (333)

[His face is so emaciated that it seems the the fire of his eyes

Rilke, Rodin and Other Prose Pieces, trans. G. Craig Houston (New York: Quartet Books, 1986), 18-19. For an account of Rilke's relationship to D'Annunzio, see George Schoolfield, "Rilke and D'Annunzio: A Painful Case," Quaderni Dannunziani 3-4 (1988): 305-21. 
must be devouring it. When he speaks, he becomes strangely agitated. It troubled me. He works, he works, he works, with a terrible fury. Perhaps he is trying to evade a thought that gnaws at him.]

The terrible "fury" with which he works is a fury's sister, the Gorgon ("lavora, lavora, lavora"-yet another geminatio that recalls Lanham's example: "O horror, horror, horror"). We can only speculate about the thought that eats away at him.

The thought that eats away at the text, however, is clear: the Medusan moment is the consequence of the decadent's occupation of the woman's body, of his appropriation of physical alterity as a figure for psychic alterity. Just as discussions of the androgyny of genius and poetic production were haunted by figures of physiological monstrosity, so is the desire for eviration haunted by its physiological "realization." In order for that desire to perpetuate itself, such a realization must remain suspended by the fetishist's disavowal. If $\mathrm{La}$ Gioconda is taken as the outcome and culmination of the decadent texts discussed here, then we can say that the "degenderation" they propose is precariously suspended from the logic of castration: if "woman" is and is not castrated, then "man," too, is and is not castrated. ${ }^{44}$ The "law" thereby transgressed is the law and logic of castration, and eroticism resonates from the fetishist's oscillation.

54. On fetishism as a "third way" out of the binary logic of castration, see Berg, 11-20. 